\title{
Carbon- and oxygen-isotope records of palaeoenvironmental and carbonate production changes in shallow-marine carbonates (Kimmeridgian, Swiss Jura)
}

\author{
CLAUDE COLOMBIÉ* $\dagger$, CHRISTOPHE LÉCUYER* \& ANDRÉ STRASSER $\ddagger$ \\ *UMR CNRS 5125 PEPS, Université Lyon 1, La Doua, bâtiment Géode, F-69622, Villeurbanne cedex, France \\ $\ddagger$ Department of Geosciences, Chemin du Musée 6, University of Fribourg, 1700 Fribourg, Switzerland
}

(Received 27 July 2009; accepted 14 April 2010; first published online 2 July 2010)

\begin{abstract}
Carbon- and oxygen-isotope ratios are commonly used to correlate shallow- and deepmarine successions. Carbon- and oxygen-isotope analyses were performed on bulk-carbonate samples from two Kimmeridgian sections of the Swiss Jura platform in order to correlate them with biostratigraphically well-dated coeval sections in the adjacent basin. On the platform, a general decrease in $\delta^{13} \mathrm{C}$ and $\delta^{18} \mathrm{O}$ values from the base to the top of the studied interval is measured, whereas time-equivalent pelagic-hemipelagic carbonates record an increase in carbon- and oxygen-isotope ratios. Moreover, the measured $\delta^{13} \mathrm{C}$ and $\delta^{18} \mathrm{O}$ values are generally lower than those indicated for the Kimmeridgian open ocean and show high-frequency variations superimposed on the general trend. Samples were screened for diagenetic alteration using optical and cathodoluminescence petrography and coupled carbon- and oxygen-isotope and trace-element analyses. Some observations favour a role for diagenetic alteration, but isotopic and elemental trends as well as sedimentological evidence suggest that the more negative values of $\delta^{13} \mathrm{C}$ and $\delta^{18} \mathrm{O}$ relative to Kimmeridgian seawater are also due to local environmental conditions. High-frequency changes in $\delta^{18} \mathrm{O}$ and $\delta^{13} \mathrm{C}$ values most likely result from variations in salinity and carbonate production and accumulation rates. These variations were produced by different water masses that were isolated from the open ocean and developed their own geochemical signatures. Repeated isolation was induced by high-frequency sea-level fluctuations and helped by irregular platform morphology. Consequently, carbon- and oxygen-isotope records in shallow-marine carbonates can be used for stratigraphic correlation only if their origin is well known.
\end{abstract}

Keywords: stable isotopes, Kimmeridgian, Swiss Jura Mountains, palaeoenvironmental parameters, carbonate production.

\section{Introduction}

Many shallow-marine carbonates do not preserve a simple geochemical record of their depositional environment because the sediments are commonly exposed to meteoric water before they have reached mineralogical stability (Allan \& Matthews, 1982). Diagenetic stabilization of the carbonate constituents is accompanied by concomitant textural and chemical changes (Brand \& Veizer, 1980, 1981). Notably, bulk matrix $\delta^{13} \mathrm{C}$ data cannot be considered to be free of diagenetic artefacts (Immenhauser, Holmden \& Patterson, 2007). For example, Immenhauser et al. (2003) explained local positive shifts in carbonate $\delta^{13} \mathrm{C}$ and $\delta^{18} \mathrm{O}$ values in a thick carbonate platform succession of Palaeozoic strata by geochemically altered platform-top water masses and the effects of early meteoric diagenesis. Furthermore, Patterson \& Walter (1994a) showed that seawater $\Sigma \mathrm{CO}_{2}$ from modern carbonate platforms (Bahama Banks and Florida) is depleted in ${ }^{13} \mathrm{C}$ by as much as $4 \%$ relative to openocean water. Similarly, Joachimski (1994) showed that Purbeckian peritidal micrites deposited in different depositional environments display distinct, facies-

$\nmid$ †uthor for correspondence: claude.colombie@univ-lyon1.fr dependent carbon-isotope ratios. Therefore, shallowmarine carbonates may develop their own isotopic signature that depends mainly on early meteoric diagenesis and local palaeoenvironmental parameters. However, an increasing number of studies note a correlation of $\delta^{13} \mathrm{C}$ values between shallow-water and deep-water successions. These studies have lent further support to the applicability of $\delta^{13} \mathrm{C}$ variations in shallow-marine carbonates for stratigraphic purposes (Immenhauser et al. 2003; Buonocunto et al. 2002; Glumac \& Walker, 1998; Grötsch, Billing \& Vahrenkamp, 1998; Immenhauser et al. 2002; Krull et al. 2004; Magaritz, 1983; Marshall \& Middleton, 1980; Swart \& Eberli, 2005; Vahrenkamp, 1996; Weissert et al. 1998).

Generally, the Kimmeridgian (Late Jurassic) can be considered as a greenhouse period (Hallam, 1985; Sellwood, Valdes \& Price, 2000). In the Swiss Jura, sedimentological and clay-mineralogical analyses of shallow-marine carbonates indicate that climate changed from more humid to more arid at the boundary between the Early and Late Kimmeridgian (Colombié, 2002). This result is consistent with the findings of several authors (Abbink et al. 2001; Hallam, 1984; Price, 1999; Rameil, 2005; Wignall \& Ruffell, 1990), who have indicated a drier phase towards the 
Jurassic/Cretaceous boundary (from the Kimmeridgian to the Early Berriasian). The Late Kimmeridgian was the end of a second-order transgression that started in the Late Oxfordian (Hardenbol et al. 1998). Despite this transgression, the Kimmeridgian of the Swiss Jura contains bioturbated mudstones with circum-granular cracks, desiccation cracks, tepees or fenestrae that indicate low-energy depositional environments between the upper intertidal and supratidal zones (Colombié \& Strasser, 2005). This implies that carbonate productivity was such that the platform could keep up with sealevel rise and even outpace it. However, there is not any sedimentary evidence of repeated and prolonged emergence (e.g. gravitational cements, vadose pisoids, alveolar structures, dissolution vugs, recrystallization of micritic matrix, or rootlet structures). These shallowwater carbonates therefore have a high potential for the preservation of the primary oxygen- and carbonisotopic compositions.

The biostratigraphy of the Kimmeridgian of the Swiss Jura platform is only poorly defined. A highresolution sequence-stratigraphic correlation with three biostratigraphically well-dated hemipelagic and pelagic sections located in the Vocontian Basin in France has been performed (Colombié \& Strasser, $2003,2005)$. The impetus for the present work was to constrain this correlation by using carbon and oxygen isotopes for correlation between the Kimmeridgian of the Swiss Jura and well-dated coeval sections in other western European basins. Carbon- and oxygenisotope analyses were made from bulk-rock samples from two Kimmeridgian sections of the Swiss Jura platform. The obtained variations in $\delta^{13} \mathrm{C}$ and $\delta^{18} \mathrm{O}$ values correlate with changes in relative sea level. However, these isotopic records differ from those obtained from the same interval in other basins. The obtained values were also compared with the $\delta^{13} \mathrm{C}$ and $\delta^{18} \mathrm{O}$ values from coeval nonluminescent belemnite rostra and brachiopods measured in previous studies (Prokoph, Shields \& Veizer, 2008; Riboulleau et al. 1998; Veizer et al. 1999; Wierzbowski, 2004), in order to identify the global versus local palaeoceanographic effects. Optical and cathodoluminescence petrography, as well as trends in elemental and isotopic data, were used in order to characterize the influence of meteoric diagenesis. Lastly, the $\delta^{13} \mathrm{C}$ and $\delta^{18} \mathrm{O}$ values were compared with the sedimentological and sequencestratigraphical interpretation of the two studied sections (Colombié, 2002; Colombié \& Strasser, 2005) in order to specify the origin of the isotopic record in the Kimmeridgian shallow-water carbonates of the Swiss Jura.

\section{Geological context}

Two Kimmeridgian platform sections, Gorges du Pichoux and Péry-Reuchenette, were studied to investigate their stable-isotope and trace-element compositions. They are located north of Biel in the central Swiss Jura (Fig. 1). During the Kimmeridgian,

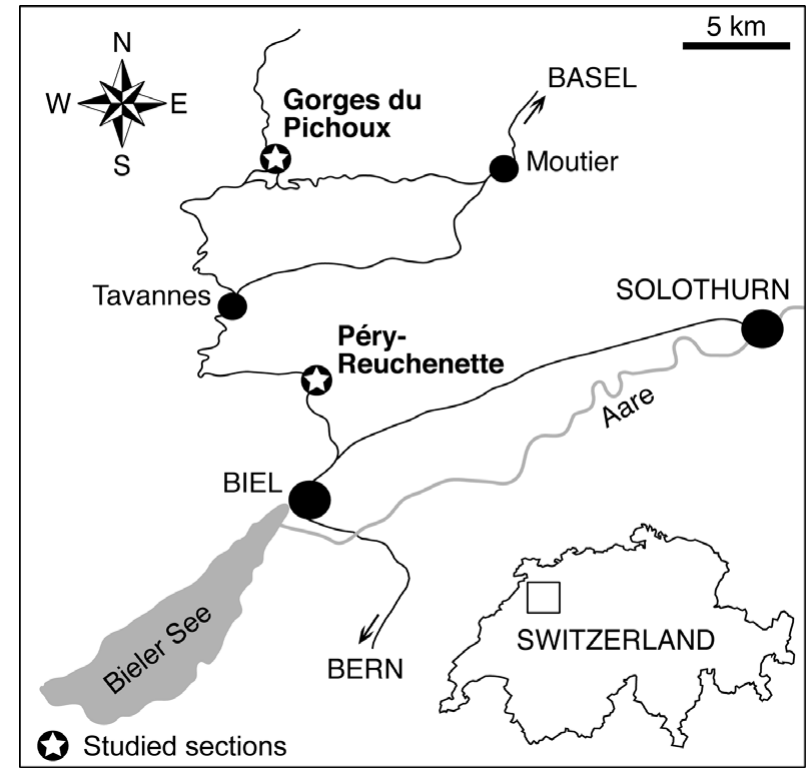

Figure 1. Geographical location of the studied sections. The Gorges du Pichoux section is in a more proximal position on the Jura platform than the Péry-Reuchenette section, and generally displays more restricted facies.

the Jura Mountains were a SW-NE-trending shallow carbonate platform located between the Paris Basin in the northwest and the Tethys Ocean in the southeast. The Gorges du Pichoux section, which is located north-northwest of the Péry-Reuchenette section, is in a more proximal position and displays generally more restricted facies. Nevertheless, both of the studied successions essentially include bioturbated mudstones and wackestones with moderate fossil diversity (ostracodes, bivalves, gastropods, miliolids, other benthic foraminifera, dasycladaceans and sponge spicules), which indicate semi-restricted lagoons (Colombié \& Strasser, 2005). Such lime mudstones exhibit high porosities but low permeabilities (Enos \& Sawatsky, 1981) that allow only minor pore-water flow. Residence time of waters within these semi-restricted lagoons was long because of weak exchange with open-ocean waters.

In the central Swiss Jura, the Kimmeridgian corresponds to the Reuchenette Formation (Gygi, 1995; Thalmann, 1966). The Reuchenette Formation lies between the white oolitic limestones of the Late Oxfordian Verena Member and the Early Tithonian 'Calcaires en Plaquettes' (Fig. 2). The ammonites of the Swiss Jura have a Tethyan affinity in the Early Kimmeridgian, while they suggest boreal influences in the Late Kimmeridgian (Gygi, 1995; Colombié \& Rameil, 2007). The top of the Verena Member belongs to the upper part of the Planula ammonite zone (Gygi \& Persoz, 1986). The upper boundary of the Reuchenette Formation corresponds to the top of the boreal Beckeri zone, which coincides with the Tethyan Autissiodorensis zone (Gygi, 1995; Meyer \& Pittman, 1994). Sedimentological and sequence analyses of the Gorges du Pichoux and Péry-Reuchenette sections 


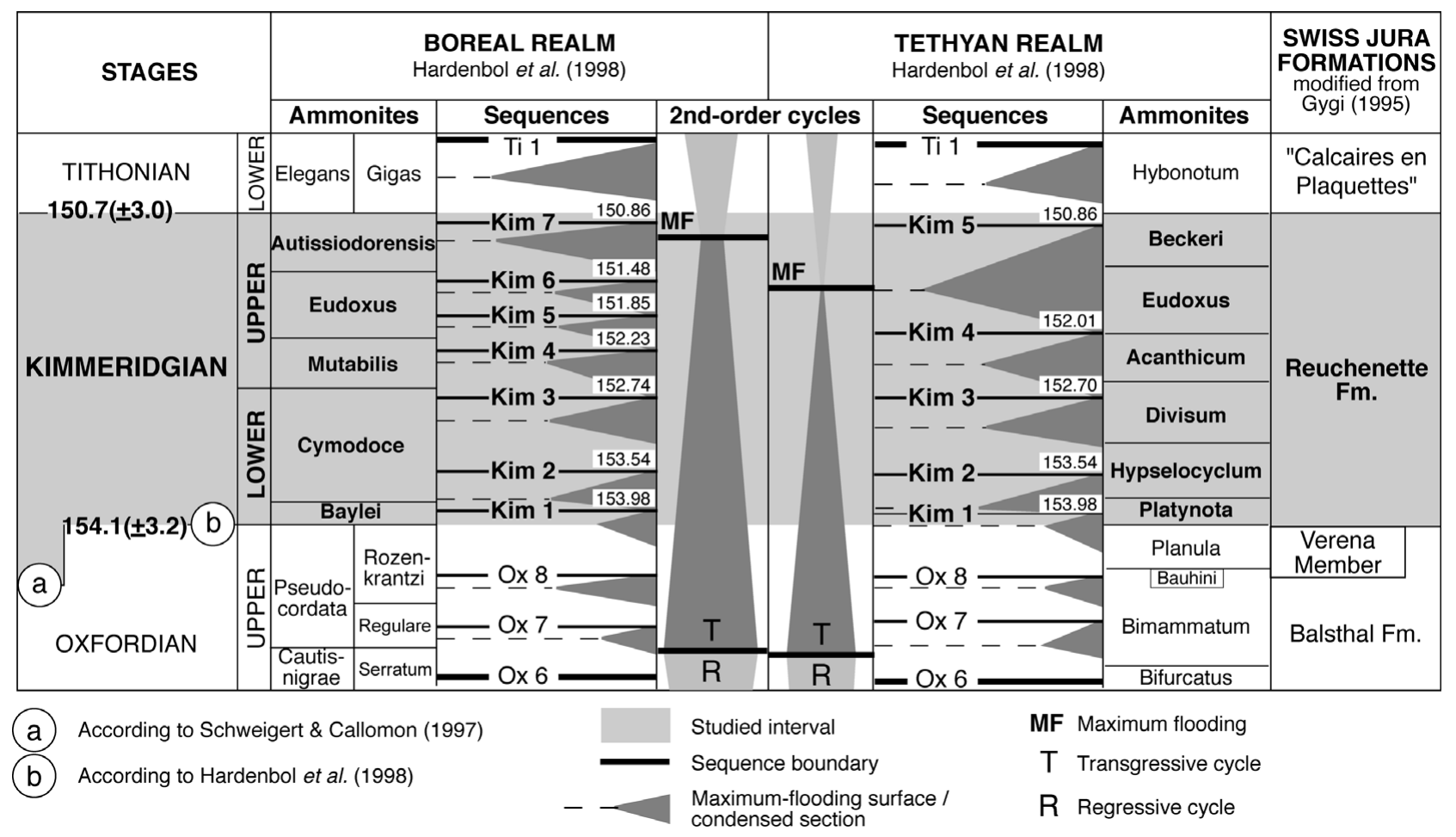

Figure 2. Stratigraphic chart for the studied interval and associated formations in the Swiss Jura. The most important increase in accommodation space in the Swiss Jura occurs in the Eudoxus ammonite zone, and coincides with the second-order maximum flooding defined by Hardenbol et al. (1998) for the Tethyan realm.

allow the definition of small-, medium- and largescale depositional sequences that are hierarchically stacked. This hierarchy partly reflects the sedimentary record of climatic and sea-level changes that were in tune with the orbital (Milankovitch) cycles: the small-scale sequences correspond to the $100 \mathrm{ka}$ short eccentricity cycle and the medium-scale sequences to the $400 \mathrm{ka}$ long eccentricity cycle. Large-scale sequences are composed of two to three mediumscale sequences (Fig. 3; Colombié, 2002; Colombié \& Strasser, 2005). The high-resolution sequencestratigraphic correlation with three biostratigraphically well-dated hemipelagic and pelagic sections located in the Vocontian Basin in France allows a better definition of the chronostratigraphic framework (Colombié \& Strasser, 2003, 2005). The most important increase in accommodation space in the Kimmeridgian of the Swiss Jura occurs in the Eudoxus ammonite zone (Late Kimmeridgian) and coincides with the end of the second-order transgression (that is, the secondorder maximum flooding) defined by Hardenbol et al. (1998) for the Tethyan realm (Fig. 2). The platformto-basin correlation also shows that the composition of hemipelagic and pelagic deposits depends, to a large extent, on cyclical variations of carbonate production in shallow-marine environments and subsequent export of carbonate mud to the basin (Colombie \& Strasser, 2003). The most important increase in accommodation space in the Kimmeridgian of the Swiss Jura corresponds to the greatest increase in carbonate production and accumulation on the platform and export to the basin. Carbonate production on the platform generally outpaced accommodation gain. Consequently, despite the second-order maximum flooding that characterized the Late Kimmeridgian, the Swiss Jura platform was prograding (Colombié \& Strasser, 2005).

\section{Sampling and methods}

Carbon- and oxygen-isotopic analyses were carried out on bulk carbonate samples from the Gorges du Pichoux and Péry-Reuchenette sections (Fig. 3). In the Gorges du Pichoux section, the whole Kimmeridgian was analysed, whereas the studied interval in the PéryReuchenette section includes the upper part of the Early Kimmeridgian and the lower part of the Late Kimmeridgian. Seventy-three samples from the Gorges du Pichoux section ( 2 or 3 metre sampling increments) and 65 samples from the Péry-Reuchenette section (1 or 2 metre sampling increments) were analysed. In order to reduce the effects of mineralogical and biological fractionations as well as diagenetic processes, finegrained and texturally uniform matrix micrites from the deepest and most open-marine environments were sampled.

Fifty-four analyses from the Gorges du Pichoux section were performed with a VG Prism mass spectrometer at the ETH of Zurich (Switzerland). Then, 62 samples from the Péry-Reuchenette section and 3 samples from the Gorges du Pichoux section were analysed with a VG Prism series 2 at the Department of Earth Sciences of the University of Oxford (United Kingdom). Standard deviations in the Péry-Reuchenette samples are $0.03 \%$ for carbon and 


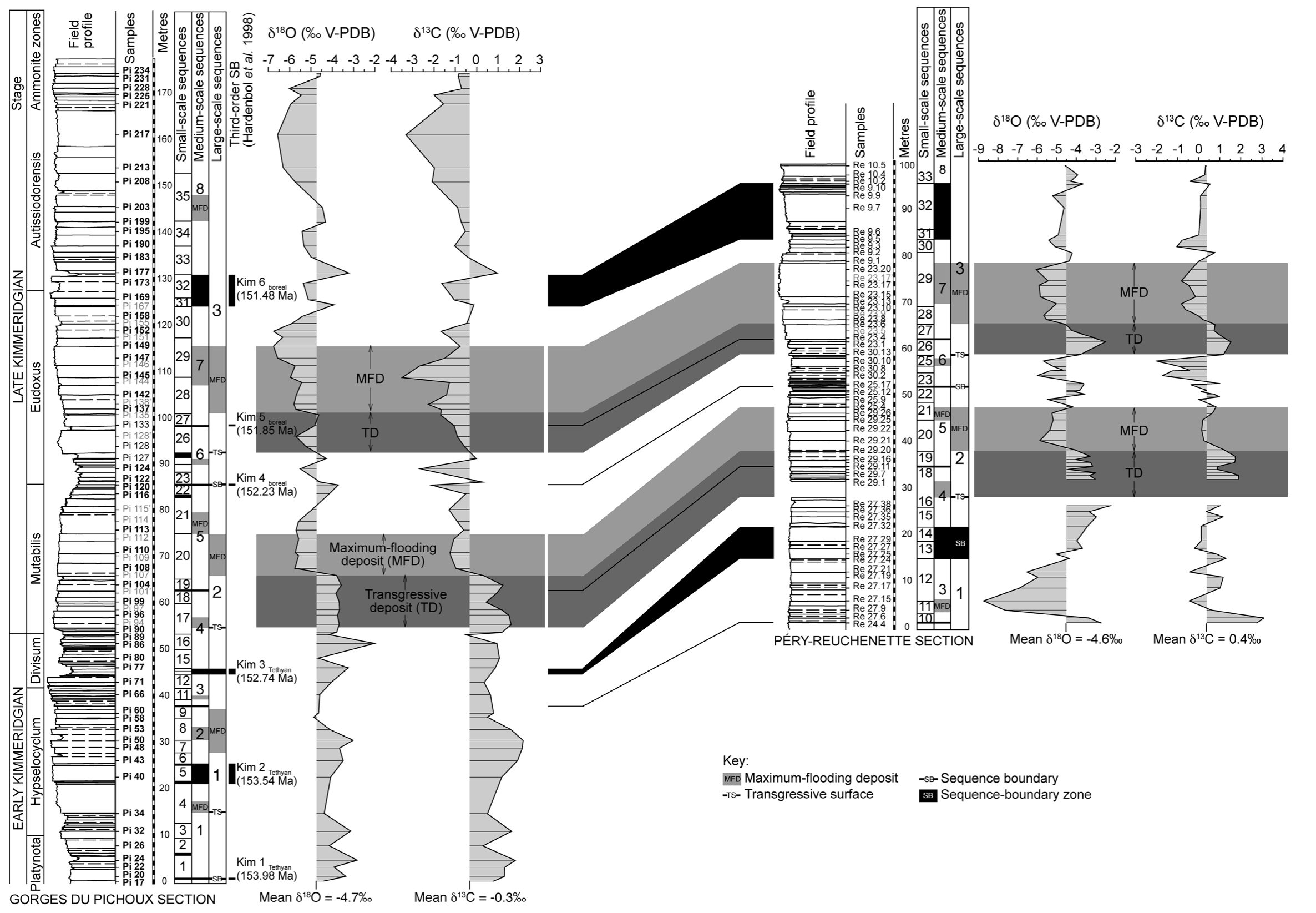

Figure 3. Correlation of oxygen- and carbon-isotope ratios between the Gorges du Pichoux and the Péry-Reuchenette sections, and comparison with the sequence-stratigraphic interpretation. Samples listed in bold type were analysed in Zurich, those in regular type in Oxford, those in grey in Lyon. In each section, changes in $\delta^{18} \mathrm{O}$ resemble those in $\delta^{13} \mathrm{C}$. Moreover, variations in oxygen- and

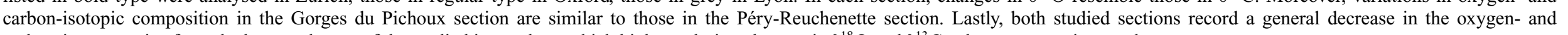
carbon-isotope ratios from the base to the top of the studied interval, on which high-resolution changes in $\delta^{18} \mathrm{O}$ and $\delta^{13} \mathrm{C}$ values are superimposed. 
0.09 to $0.1 \%$ for oxygen, while they are $0.06 \%$ for carbon and $0.1 \%$ for oxygen in the Gorges du Pichoux samples. Isotopic results are reported in per mil deviation from the V-PDB (Vienna Pee Dee Belemnite) using the standard delta notation. Lastly, 16 samples from the Gorges du Pichoux section and 3 samples from the Péry-Reuchenette section were analysed with a GV Instruments MultiPrep carbonate preparation device directly coupled to a GV Instruments IsoPrime mass spectrometer at the UMR CNRS 5125 of the University of Lyon 1 (France). Precision is better than $0.03 \%$ for carbon and $0.09 \%$ for oxygen.

Parallel to carbon- and oxygen-isotopic analyses, $\mathrm{Sr}, \mathrm{Mg}, \mathrm{Na}, \mathrm{Fe}$ and $\mathrm{Mn}$ contents in bulk carbonate samples from the Gorges du Pichoux and PéryReuchenette sections were measured. The sampling procedure was the same as the one followed for carbon- and oxygen-isotope analyses. Then, around $15 \mathrm{~g}$ of rock were washed in demineralized water, dried in an oven at $80^{\circ} \mathrm{C}$, and powdered very finely. Fifty-five samples from the Gorges du Pichoux were analysed at the University of Dijon. Trace element concentrations in the carbonate fraction (acetic acid soluble fraction) were measured by atomic mass spectrophotometry following the standard procedure developed by Renard \& Blanc (1971) and Richebois (1990). Sixty-two samples from the Péry-Reuchenette section were analysed at the Department of Earth Sciences of the University of Oxford. There, $40 \mathrm{mg}$ of powder were dissolved in $1 \mathrm{~mol} / \mathrm{l}$ acetic acid. The resulting sample solution was centrifuged to remove the residual phase. After adding an internal standard to the sample solution, it was diluted for the ICP mass spectrometer using $1 \% \mathrm{HNO}_{3}$.

Stable-isotope and trace-element compositions were compared to each other (for different time intervals) by using reduced major axis (RMA) linear fitting (Davis, 2002). Scatter diagrams include statistical results. For each couple of variables, we calculated the Pearson correlation coefficient $(r)$ in order to estimate the overall quality of the linear relations (the closer to \pm 1 , the better the linear relation). A significance t-test associated with this correlation coefficient indicates how far the sampled data are from the null hypothesis $\left(\mathrm{H}_{0}\right)$ of no linear relationship between the two variables. A low p-value (classically, $<0.05$ ) refers to couples of variables whose linear relationship cannot be explained by sampling chance. Scatter diagrams include the estimated RMA lines only in this case. However, the correlation of time series of stable-isotope or trace-element compositions can be affected by timeautocorrelation effects. Estimating and testing for significance correlations calculated between timedifferentiated variables (e.g. $\delta^{18} \mathrm{O}_{\mathrm{t}+1}-\delta^{18} \mathrm{O}_{\mathrm{t}}$ and $\left.\delta^{13} C_{t+1}-\delta^{13} C_{t}\right)$ can easily eliminate this problem. Still, significant correlation between such differentiated variables indicates that the correlation between the two original variables is not a spurious artefact of timeautocorrelation. An analysis of covariance (ANCOVA; Sokal \& Rohlf, 1995) was performed in order to test for significance the null hypothesis that a same $\delta^{13} \mathrm{C}$ versus $\delta^{18} \mathrm{O}$ linear relation model holds for the various depositional environments, that is, that all the estimated regression lines are statistically equivalent. Here, a low p-value (classically, <0.05) indicates that the compared samples actually refer to two or more distinct sets of linear relations. We further investigated the relationship between the ranked depositional environments along a more open-marine to more restricted gradient and the linear regression intercepts used for the ANCOVA (that is, the $\delta^{18} \mathrm{O}$-values predicted by the sampled linear models for $\delta^{13} \mathrm{C}=0$ ). We used the Kendall rank correlation coefficient $(\tau)$ and its associated significance test $\left(\mathrm{H}_{0}: \tau=0\right)$ (Abdi, 2007; Kendall \& Gibbons, 1990). Kendall's $\tau$ is a robust (nonparametric) measure for nonlinear but monotonous relationship between two variables (the closer to \pm 1 , the stronger the correspondence between the two sets of ranked values).

Ten thin-sections from the Gorges du Pichoux were investigated with cathodoluminescence microscopy (CL MK3a, $17 \mathrm{kV}$ gun voltage, $450 \mu \mathrm{A}$ gun current). They are located below, in and above the transgressive and maximum-flooding deposits of the second and third large-scale sequences (Fig. 3).

\section{Results}

Results of the carbon- and oxygen-isotopic analyses from the Gorges du Pichoux and Péry-Reuchenette sections are plotted in Figure 3 and listed in Table 1. In the Gorges du Pichoux section, $\delta^{13} \mathrm{C}$ and $\delta^{18} \mathrm{O}$ values fluctuate to a large part in covariance and generally resemble those from the Péry-Reuchenette section (Fig. 3). Carbon- and oxygen-isotope values in the Gorges du Pichoux section range from -3.5 to $2.2 \%$ and from -6.7 to $-2 \%$, respectively (Table 1 ). The mean values are $-0.3 \pm 1.4 \%$ for $\delta^{13} \mathrm{C}$ and $-4.7 \pm 1.1 \%$ for $\delta^{18} \mathrm{O}$. The lowest $\delta^{13} \mathrm{C}$ and $\delta^{18} \mathrm{O}$ values from the Péry-Reuchenette section are $-2 \%$ o and $-8.7 \%$, respectively; the highest values are $3.1 \%$ o and $-2.2 \%$. The mean $\delta^{13} \mathrm{C}$ and $\delta^{18} \mathrm{O}$ values are $0.4 \pm 1 \%$ and $-4.6 \pm 1.2 \%$ o, respectively. In both the Gorges du Pichoux and Péry-Reuchenette sections, the deviation from the mean value to the lowest value and highest value is at least one order greater than the standard deviation, indicating that fluctuations in $\delta^{13} \mathrm{C}$ and $\delta^{18} \mathrm{O}$ values are meaningful. $\delta^{13} \mathrm{C}$ and $\delta^{18} \mathrm{O}$ values generally decrease from the base to the top of both studied sections. Most $\delta^{13} \mathrm{C}$ and $\delta^{18} \mathrm{O}$ values are higher than the mean value in the lower part of the studied interval, whereas most of them are lower than the mean value in the upper part. The mean $\delta^{13} \mathrm{C}$ and $\delta^{18} \mathrm{O}$ values are lower at Gorges du Pichoux, which is the more proximal section, than at Péry-Reuchenette. The standard deviations for $\delta^{13} \mathrm{C}$ and $\delta^{18} \mathrm{O}$ values in the Gorges du Pichoux section are higher than those in the Péry-Reuchenette section.

Moreover, $\left(\delta^{13} \mathrm{C}, \delta^{18} \mathrm{O}\right)$ scatter diagrams for the Gorges du Pichoux and Péry-Reuchenette sections 
Table 1. Carbon- and oxygen-isotope ratios (\%o V-PDB) from the Gorges du Pichoux (samples Pi) and Péry-Reuchenette (samples Re) sections

\begin{tabular}{|c|c|c|c|c|c|c|c|c|c|c|c|c|c|c|}
\hline Samples & $\delta^{13} \mathrm{C}$ & $\delta^{18} \mathrm{O}$ & Samples & $\delta^{13} \mathrm{C}$ & $\delta^{18} \mathrm{O}$ & Samples & $\delta^{13} \mathrm{C}$ & $\delta^{18} \mathrm{O}$ & Samples & $\delta^{13} \mathrm{C}$ & $\delta^{18} \mathrm{O}$ & Samples & $\delta^{13} \mathrm{C}$ & $\delta^{18} \mathrm{O}$ \\
\hline \multicolumn{15}{|c|}{ Gorges du Pichoux } \\
\hline Pi 17 & 0.8 & -4.4 & Pi 77 & 0.9 & -3.2 & Pi 113 & -0.6 & -5.7 & Pi 145 & -3.5 & -6.0 & Pi 203 & -0.9 & -4.4 \\
\hline Pi 20 & 1.3 & -3.3 & Pi 80 & 1.1 & -4.6 & Pi 114 & -0.9 & -5.6 & Pi 146 & -2.7 & -5.7 & Pi 208 & -2.1 & -5.7 \\
\hline Pi 22 & 1.3 & -3.9 & Pi 86 & 1.0 & -2.0 & Pi $115^{\prime}$ & -1.3 & -4.9 & Pi 147 & -1.5 & -6.5 & Pi 213 & -2.0 & -6.3 \\
\hline Pi 24 & 1.8 & -2.8 & Pi 89 & -0.5 & -4.1 & Pi 116 & -0.5 & -4.1 & Pi 149 & -0.8 & -6.7 & Pi 217 & -3.3 & -6.6 \\
\hline Pi 26 & 0.3 & -4.1 & Pi 90 & 1.2 & -3.8 & Pi 120 & -2.1 & -3.7 & Pi 151 & -1.2 & -6.3 & Pi 221 & -1.5 & -5.9 \\
\hline Pi 32 & 1.6 & -3.1 & Pi 94 & 1.6 & -3.7 & Pi 122 & 0.3 & -4.6 & Pi 152 & -1.7 & -6.7 & Pi 225 & -2.0 & -5.4 \\
\hline Pi 34 & 0.5 & -4.4 & Pi 96 & 1.5 & -3.7 & Pi 124 & -2.6 & -5.5 & Pi 155 & -0.4 & -5.9 & Pi 228 & -0.7 & -6.0 \\
\hline Pi 40 & 1.2 & -4.1 & Pi 97 & 1.2 & -3.6 & Pi 127 & 0.0 & -4.3 & Pi 158 & -0.3 & -5.4 & Pi 231 & -0.8 & -4.6 \\
\hline Pi 43 & 1.9 & -3.5 & Pi 99 & 0.4 & -3.7 & Pi 128 & -0.6 & -5.2 & Pi 167 & -0.1 & -3.9 & Pi 234 & -0.8 & -4.5 \\
\hline $\mathrm{Pi} 48$ & 2.1 & -3.6 & Pi 101' & 0.9 & -3.8 & Pi $128^{\prime}$ & -0.9 & -5.7 & Pi 169 & -1.0 & -5.1 & & & \\
\hline Pi 50 & 2.2 & -3.0 & Pi 104 & 1.2 & -3.6 & Pi 133 & -1.0 & -4.8 & Pi 173 & -1.6 & -5.3 & Minimum & -3.5 & -6.7 \\
\hline Pi 53 & 1.6 & -4.1 & Pi 107 & 0.3 & -3.8 & Pi 135 & -1.7 & -4.6 & Pi 177 & 1.0 & -3.2 & Maximum & 2.2 & -2.0 \\
\hline Pi 58 & 0.5 & -4.9 & Pi 108 & -1.0 & -5.7 & Pi 137 & -1.6 & -5.7 & Pi 183 & -0.4 & -5.0 & Mean & -0.3 & -4.7 \\
\hline Pi 60 & 0.8 & -4.6 & Pi 109 & -1.2 & -5.6 & Pi $138^{\prime}$ & -2.2 & -5.8 & Pi 190 & -1.0 & -5.3 & $\sigma$ & 1.4 & 1.1 \\
\hline Pi 66 & 0.7 & -4.6 & Pi 110 & -1.2 & -5.7 & Pi 142 & -1.4 & -5.7 & Pi 195 & -0.5 & -5.4 & & & \\
\hline Pi 71 & 0.4 & -4.0 & Pi 112 & -1.1 & -5.6 & Pi 144 & -1.3 & -5.4 & Pi 199 & -0.7 & -4.3 & & & \\
\hline \multicolumn{15}{|c|}{ Péry-Reuchenette } \\
\hline $\operatorname{Re} 24.4$ & 2.8 & -2.7 & $\operatorname{Re} 27.38$ & 1.0 & -2.2 & $\operatorname{Re} 25.4$ & 0.8 & -4.2 & $\operatorname{Re} 23.1$ & 1.5 & -2.5 & $\operatorname{Re} 9.3$ & -1.0 & -5.1 \\
\hline $\operatorname{Re} 27.6$ & 3.1 & -3.4 & $\operatorname{Re} 29.1$ & 1.9 & -3.0 & $\operatorname{Re} 2$ & 0.0 & -5.5 & & 1.2 & -3.1 & $\operatorname{Re} 9$ & -0.8 & -5.4 \\
\hline 27.9 & 0.6 & -7.6 & $\operatorname{Re} 29.5$ & 1.9 & -3.3 & $\operatorname{Re} 25.11$ & 1.0 & -4.5 & $\operatorname{Re} 23.5$ & 0.7 & -4.2 & $\operatorname{Re} 9.6$ & 0.0 & -4.9 \\
\hline $\operatorname{Re} 27.15$ & -0.4 & -8.7 & $\operatorname{Re} 29.7$ & 1.5 & -3.0 & $\operatorname{Re} 25.12$ & 0.7 & -3.6 & $\operatorname{Re} 23.6$ & 0.8 & -4.5 & $\operatorname{Re} 9.7$ & 0.1 & -4.6 \\
\hline $\operatorname{Re} 27.17$ & 1.0 & -6.9 & $\operatorname{Re} 29.9$ & 0.9 & -4.4 & $\operatorname{Re} 25.14$ & 0.1 & -4.1 & & 0.2 & -5.5 & $\operatorname{Re} 9.9$ & 0.1 & -5.2 \\
\hline 27.19 & 1.2 & -6.0 & $\operatorname{Re} 29.11$ & 0.9 & -3.2 & $\operatorname{Re} 25.15$ & 0.4 & -3.8 & $\operatorname{Re} 23.9^{\prime}$ & -0.1 & -5.7 & $\operatorname{Re} 9.10$ & 0.5 & -3.7 \\
\hline $\operatorname{Re} 27.21$ & -0.4 & -6.5 & $\operatorname{Re} 29.13$ & 1.7 & -3.3 & $\operatorname{Re} 25.17$ & -0.4 & -3.6 & $\operatorname{Re} 23.10$ & -0.6 & -5.3 & $\operatorname{Re} 10.2$ & -0.4 & -4.3 \\
\hline $\operatorname{Re} 27.24$ & 1.3 & -4.4 & $\operatorname{Re} 29.16$ & 1.7 & -4.0 & $\operatorname{Re} 25.18$ & 1.0 & -3.6 & $\operatorname{Re} 23.13$ & -0.8 & -5.0 & $\operatorname{Re} 10.4$ & 0.3 & -3.9 \\
\hline $\operatorname{Re} 27.25$ & 0.8 & -5.0 & $\operatorname{Re} 29.17$ & 1.7 & -3.3 & $\operatorname{Re} 30.2$ & -1.7 & -6.0 & $\operatorname{Re} 23.15$ & -0.1 & -5.8 & $\operatorname{Re} 10.5$ & 0.3 & -4.6 \\
\hline $\operatorname{Re} 27.27$ & -0.2 & -3.7 & $\operatorname{Re} 29.20$ & 1.2 & -4.0 & $\operatorname{Re} 30.5$ & -1.2 & -5.3 & $\operatorname{Re} 23.17$ & -0.5 & -5.9 & & & \\
\hline $\operatorname{Re} 27.29$ & 0.1 & -4.0 & $\operatorname{Re} 29.21$ & 0.2 & -5.9 & $\operatorname{Re} 30.6$ & -0.4 & -4.7 & $\operatorname{Re} 23.17^{\prime}$ & -0.8 & -5.5 & Minin & -2.0 & -8.7 \\
\hline $\operatorname{Re} 27.32$ & 0.1 & -3.4 & $\operatorname{Re} 29.22$ & 0.1 & -5.3 & $\operatorname{Re} 30.8$ & -0.9 & -5.2 & $\operatorname{Re} 23.20$ & -0.4 & -6.1 & Maximum & 3.1 & -2.2 \\
\hline $\operatorname{Re} 27.35$ & 1.2 & -3.0 & $\operatorname{Re} 29.25$ & 0.2 & -5.2 & Re 30.10 & -2.0 & -5.7 & Re 9.1 & 0.0 & -4.4 & Mean & 0.4 & -4.6 \\
\hline $\operatorname{Re} 27.36$ & 0.4 & -3.4 & Re 29.26 & 0.7 & -5.2 & $\operatorname{Re} 30.13$ & 1.2 & -3.8 & $\operatorname{Re} 9.2$ & 0.8 & -4.2 & $\sigma$ & 1.0 & 1.2 \\
\hline
\end{tabular}

Samples in bold type were analysed in Zurich, those in regular type in Oxford, those in italic type in Lyon. $\sigma$ is standard deviation.

show that carbon- and oxygen-isotope ratios behave as interrelated variables when including the whole studied interval or when looking only at its lower or upper part where most $\delta^{13} \mathrm{C}$ and $\delta^{18} \mathrm{O}$ values are higher or lower than the mean values, respectively (Fig. 4).

The comparison between the stable isotope records and the sequence-stratigraphical interpretation reveals high-frequency $\delta^{13} \mathrm{C}$ and $\delta^{18} \mathrm{O}$ changes: (1) $\delta^{13} \mathrm{C}$ and $\delta^{18} \mathrm{O}$ values that are higher than the mean values in the transgressive deposit (TD) of the second largescale sequence; (2) $\delta^{13} \mathrm{C}$ and $\delta^{18} \mathrm{O}$ values that are lower than the mean values in the maximum-flooding deposit (MFD) of the second large-scale sequence; (3) a positive shift in $\delta^{13} \mathrm{C}$ and $\delta^{18} \mathrm{O}$ values in the TD of the third large-scale sequence in the PéryReuchenette section but a coeval negative shift in the Gorges du Pichoux section; and (4) a negative shift in $\delta^{13} \mathrm{C}$ and $\delta^{18} \mathrm{O}$ values in the MFD of the third largescale sequence (Fig. 3). The main excursions discussed here are defined by numerous data points and are not the effects of simply one or a few samples deviating from the mean. The highstand and lowstand deposits display very irregular patterns in the isotope curves that are difficult to correlate from one section to the other.

Strontium, $\mathrm{Mg}, \mathrm{Na}, \mathrm{Fe}$ and $\mathrm{Mn}$ contents in the Gorges du Pichoux and Péry-Reuchenette sections are listed in Tables 2 and 3, respectively. Strontium contents vary from 37 to $226 \mathrm{ppm}$ in the Gorges du
Pichoux section, and from 93 to 219 ppm in the PéryReuchenette section. Magnesium contents range from 1052 to $8839 \mathrm{ppm}$ in the Gorges du Pichoux section, and from 516 to $17539 \mathrm{ppm}$ in the Péry-Reuchenette section. Only the samples from the Gorges du Pichoux section include $\mathrm{Na}$, whose contents vary from 113 to $283 \mathrm{ppm}$. Iron contents fluctuate from 138 to $626 \mathrm{ppm}$ in the Gorges du Pichoux section, and from 0 to $345 \mathrm{ppm}$ in the Péry-Reuchenette section. Manganese contents range from 40 to $122 \mathrm{ppm}$ in the Gorges du Pichoux section, and from 18 to 90 ppm in the PéryReuchenette section.

All samples investigated with cathodoluminescence microscopy are luminescent (Fig. 5). They show yellow to orange and orange to red homogeneous luminescence. Most bioclasts show the same colour as the matrix. Iron oxides and cements tend to be brown to black.

\section{Discussion}

\section{5.a. General carbon- and oxygen-isotopic trends in the Kimmeridgian}

The end of the second-order transgression (secondorder maximum flooding), which characterizes the Eudoxus zone in the Tethyan realm (Fig. 2), coincides with the MFD of the third large-scale sequence. There, 

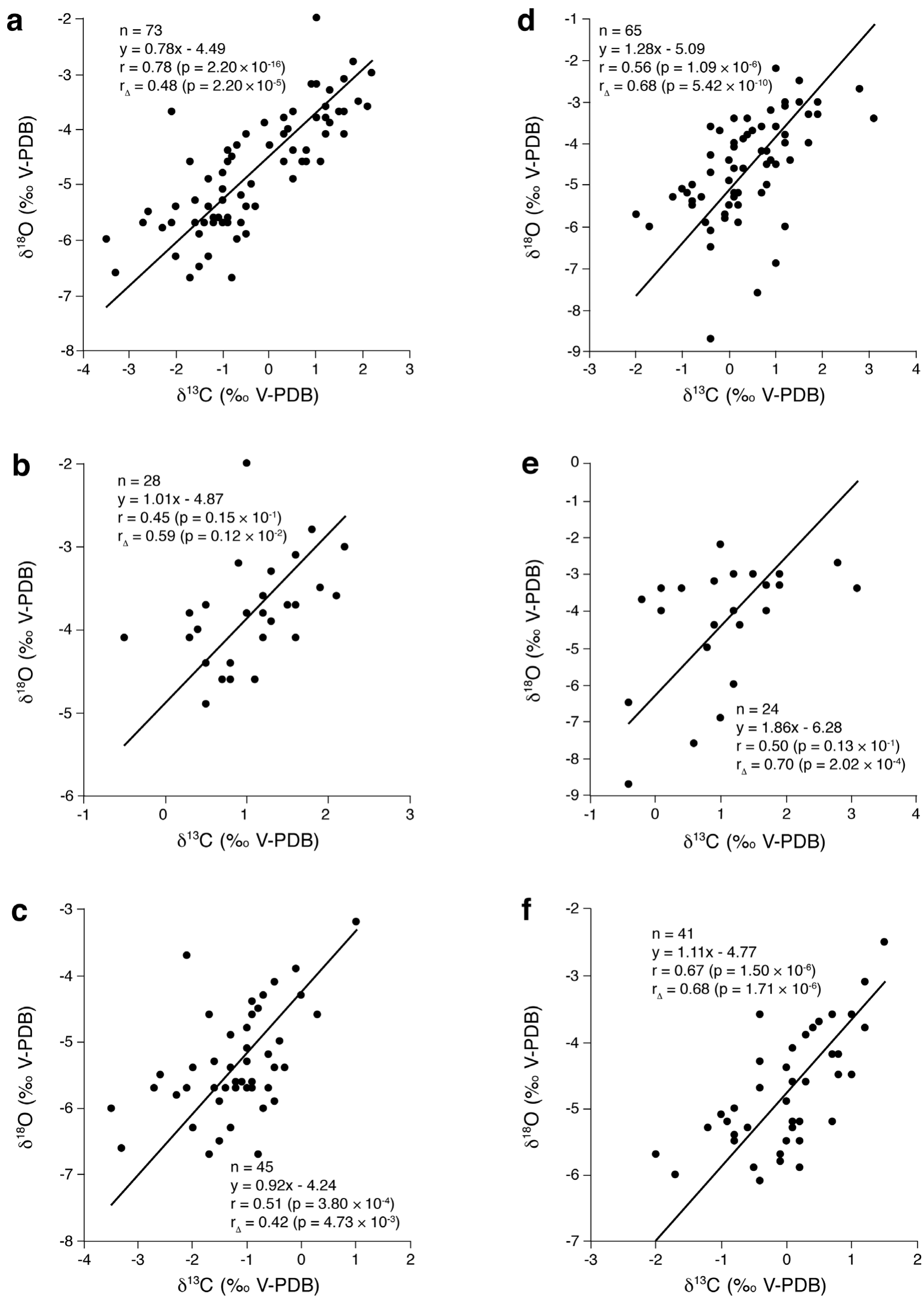

Figure 4. $\left(\delta^{13} \mathrm{C}, \delta^{18} \mathrm{O}\right)$ scatter diagrams for: (a) the whole Gorges du Pichoux section, (b) the lower part (from Pi 17 to Pi 107$)$ and (c) the upper part (from Pi 108 to Pi 234) of the Gorges du Pichoux section; (d) the whole Péry-Reuchenette section, (e) the lower part (from Re 24.4 to Re 29.20) and (f) the upper part (from Re 29.21 to Re 10.5) of the Péry-Reuchenette section. $\delta^{13} \mathrm{C}$ and $\delta^{18} \mathrm{O}$ values are interrelated variables whatever the studied section and interval. 
Table 2. $\mathrm{Sr}, \mathrm{Mg}, \mathrm{Na}, \mathrm{Fe}$ and $\mathrm{Mn}$ contents (ppm) in the Gorges du Pichoux samples

\begin{tabular}{|c|c|c|c|c|c|c|c|c|c|c|c|c|c|c|c|c|c|}
\hline Samples & $\mathrm{Sr}$ & $\mathrm{Mg}$ & $\mathrm{Na}$ & $\mathrm{Fe}$ & $\mathrm{Mn}$ & Samples & $\mathrm{Sr}$ & $\mathrm{Mg}$ & $\mathrm{Na}$ & $\mathrm{Fe}$ & $\mathrm{Mn}$ & Samples & $\mathrm{Sr}$ & $\mathrm{Mg}$ & $\mathrm{Na}$ & $\mathrm{Fe}$ & $\mathrm{Mn}$ \\
\hline Pi 17 & 129 & 2075 & 161 & 329 & 49 & Pi 96 & 131 & 2782 & 221 & 368 & 93 & Pi 173 & 37 & 1340 & 130 & 217 & 78 \\
\hline Pi 20 & 105 & 2449 & 193 & 327 & 47 & Pi 99 & 124 & 2619 & 206 & 302 & 91 & Pi 177 & 115 & 3038 & 241 & 323 & 121 \\
\hline Pi 22 & 102 & 2408 & 199 & 372 & 49 & Pi 104 & 172 & 2983 & 246 & 533 & 108 & Pi 183 & 47 & 1427 & 159 & 299 & 88 \\
\hline Pi 24 & 116 & 2662 & 264 & 429 & 55 & Pi 108 & 67 & 1935 & 128 & 306 & 45 & Pi 190 & 46 & 1700 & 200 & 214 & 98 \\
\hline Pi 26 & 84 & 1991 & 156 & 273 & 40 & Pi 110 & 45 & 1052 & 124 & 353 & 43 & Pi 195 & 48 & 1267 & 146 & 242 & 92 \\
\hline Pi 32 & 134 & 2745 & 230 & 310 & 41 & Pi 113 & 67 & 1145 & 138 & 320 & 49 & Pi 199 & 60 & 1909 & 167 & 286 & 79 \\
\hline Pi 34 & 118 & 2212 & 229 & 420 & 42 & Pi $115^{\prime}$ & 151 & 2313 & 186 & 408 & 74 & Pi 203 & 47 & 1359 & 142 & 248 & 92 \\
\hline $\mathrm{Pi} 40$ & 111 & 2261 & 197 & 608 & 62 & Pi 116 & 110 & 2391 & 204 & 402 & 73 & Pi 208 & 47 & 1347 & 125 & 289 & 81 \\
\hline Pi 43 & 146 & 2813 & 248 & 423 & 71 & Pi 120 & 226 & 3231 & 235 & 626 & 67 & Pi 213 & 47 & 1382 & 120 & 237 & 118 \\
\hline $\mathrm{Pi} 48$ & 146 & 3003 & 283 & 511 & 71 & Pi 122 & 195 & 4485 & 235 & 457 & 69 & Pi 217 & 39 & 1110 & 113 & 253 & 73 \\
\hline Pi 50 & 147 & 2956 & 260 & 492 & 65 & Pi 124 & 162 & 4294 & 203 & 402 & 71 & Pi 221 & 66 & 1305 & 124 & 138 & 75 \\
\hline Pi 53 & 132 & 2656 & 202 & 464 & 67 & Pi 128 & 67 & 1162 & 114 & 217 & 119 & Pi 225 & 72 & 1285 & 140 & 201 & 105 \\
\hline Pi 58 & 93 & 1793 & 148 & 382 & 58 & Pi 137 & 67 & 1364 & 159 & 239 & 102 & Pi 228 & 68 & 1344 & 114 & 223 & 104 \\
\hline Pi 60 & 109 & 2061 & 159 & 375 & 56 & Pi 142 & 61 & 1311 & 147 & 222 & 103 & Pi 231 & 73 & 1357 & 138 & 197 & 92 \\
\hline Pi 66 & 111 & 1992 & 173 & 374 & 55 & Pi 145 & 80 & 1547 & 148 & 289 & 119 & Pi 234 & 87 & 1645 & 166 & 203 & 98 \\
\hline $\mathrm{Pi} 71$ & 113 & 2956 & 208 & 351 & 64 & Pi 147 & 51 & 1419 & 127 & 251 & 85 & & & & & & \\
\hline Pi 77 & 169 & 8839 & 262 & 606 & 70 & Pi 149 & 61 & 1229 & 141 & 219 & 75 & Minimum & 37 & 1052 & 113 & 138 & 40 \\
\hline Pi 80 & 153 & 2381 & 182 & 393 & 46 & Pi 152 & 44 & 1126 & 162 & 213 & 91 & Maximum & 226 & 8839 & 283 & 626 & 122 \\
\hline Pi 89 & 207 & 3555 & 209 & 539 & 100 & Pi 158 & 69 & 1597 & 140 & 234 & 102 & Mean & 100 & 2193 & 178 & 337 & 78 \\
\hline Pi 90 & 144 & 2564 & 195 & 367 & 84 & Pi 169 & 58 & 1447 & 133 & 237 & 122 & $\sigma$ & 47 & 1219 & 46 & 116 & 23 \\
\hline
\end{tabular}

Analyses were performed in collaboration with Laurent Emmanuel at the University of Dijon. $\sigma$ is standard deviation.

Table 3. Sr, Mg, Fe and Mn contents (ppm) in the Péry-Reuchenette samples

\begin{tabular}{|c|c|c|c|c|c|c|c|c|c|c|c|c|c|c|}
\hline Samples & $\mathrm{Sr}$ & $\mathrm{Mg}$ & $\mathrm{Fe}$ & $\mathrm{Mn}$ & Samples & $\mathrm{Sr}$ & $\mathrm{Mg}$ & $\mathrm{Fe}$ & $\mathrm{Mn}$ & Samples & $\mathrm{Sr}$ & $\mathrm{Mg}$ & $\mathrm{Fe}$ & $\mathrm{Mn}$ \\
\hline $\operatorname{Re} 24.4$ & 136 & 1690 & 142 & 18 & $\operatorname{Re} 29.20$ & 166 & 1692 & 0 & 33 & $\operatorname{Re} 23.10$ & 115 & 599 & 0 & 59 \\
\hline Re 27.6 & 146 & 1996 & 192 & 22 & $\operatorname{Re} 29.21$ & 139 & 1176 & 43 & 22 & $\operatorname{Re} 23.13$ & 110 & 812 & 0 & 34 \\
\hline $\operatorname{Re} 27.9$ & 145 & 1945 & 107 & 23 & $\operatorname{Re} 29.22$ & 143 & 1154 & 36 & 32 & $\operatorname{Re} 23.15$ & 153 & 940 & 0 & 44 \\
\hline $\operatorname{Re} 27.15$ & 158 & 4118 & 198 & 27 & $\operatorname{Re} 29.25$ & 152 & 1123 & 0 & 35 & $\operatorname{Re} 23.17$ & 124 & 606 & 0 & 39 \\
\hline $\operatorname{Re} 27.17$ & 167 & 1890 & 143 & 26 & $\operatorname{Re} 29.26$ & 194 & 1231 & 0 & 39 & $\operatorname{Re} 23.20$ & 117 & 516 & 0 & 26 \\
\hline $\operatorname{Re} 27.19$ & 111 & 1488 & 81 & 18 & $\operatorname{Re} 25.4$ & 200 & 1754 & 0 & 21 & $\operatorname{Re} 9.1$ & 121 & 843 & 0 & 27 \\
\hline $\operatorname{Re} 27.21$ & 104 & 2411 & 139 & 34 & $\operatorname{Re} 25.9$ & 157 & 836 & 0 & 34 & $\operatorname{Re} 9.2$ & 123 & 927 & 0 & 27 \\
\hline $\operatorname{Re} 27.24$ & 143 & 1749 & 87 & 30 & $\operatorname{Re} 25.11$ & 189 & 1367 & 0 & 37 & $\operatorname{Re} 9.3$ & 105 & 624 & 0 & 42 \\
\hline $\operatorname{Re} 27.25$ & 144 & 1472 & 89 & 29 & $\operatorname{Re} 25.12$ & 164 & 1425 & 1 & 36 & $\operatorname{Re} 9.5$ & 100 & 909 & 0 & 24 \\
\hline $\operatorname{Re} 27.27$ & 151 & 2029 & 161 & 44 & $\operatorname{Re} 25.14$ & 157 & 1745 & 0 & 34 & $\operatorname{Re} 9.6$ & 102 & 707 & 0 & 28 \\
\hline $\operatorname{Re} 27.29$ & 129 & 1828 & 87 & 54 & $\operatorname{Re} 25.15$ & 165 & 1519 & 0 & 33 & $\operatorname{Re} 9.7$ & 107 & 663 & 0 & 26 \\
\hline $\operatorname{Re} 27.32$ & 187 & 3219 & 96 & 65 & $\operatorname{Re} 25.17$ & 132 & 1164 & 0 & 47 & $\operatorname{Re} 9.9$ & 114 & 610 & 0 & 23 \\
\hline $\operatorname{Re} 27.35$ & 149 & 10931 & 293 & 57 & $\operatorname{Re} 25.18$ & 189 & 3419 & 0 & 36 & $\operatorname{Re} 9.10$ & 101 & 742 & 0 & 39 \\
\hline $\operatorname{Re} 27.36$ & 172 & 6726 & 181 & 40 & $\operatorname{Re} 30.2$ & 148 & 2848 & 0 & 22 & $\operatorname{Re} 10.2$ & 126 & 846 & 0 & 36 \\
\hline $\operatorname{Re} 27.38$ & 119 & 17539 & 345 & 54 & Re 30.5 & 93 & 1324 & 0 & 27 & $\operatorname{Re} 10.4$ & 130 & 770 & 0 & 54 \\
\hline $\operatorname{Re} 29.1$ & 138 & 1929 & 71 & 52 & $\operatorname{Re} 30.6$ & 219 & 1473 & 0 & 31 & $\operatorname{Re} 10.5$ & 173 & 713 & 0 & 34 \\
\hline $\operatorname{Re} 29.5$ & 180 & 2522 & 25 & 90 & Re 30.8 & 128 & 1399 & 0 & 33 & & & & & \\
\hline Re 29.7 & 195 & 5302 & 0 & 81 & $\operatorname{Re} 30.10$ & 122 & 2048 & 0 & 38 & Minimum & 93 & 516 & 0 & 18 \\
\hline $\operatorname{Re} 29.9$ & 170 & 2189 & 0 & 63 & $\operatorname{Re} 30.13$ & 137 & 1223 & 0 & 30 & Maximum & 219 & 17539 & 345 & 90 \\
\hline $\operatorname{Re} 29.11$ & 183 & 2419 & 0 & 60 & $\operatorname{Re} 23.1$ & 99 & 14648 & 0 & 57 & Mean & 144 & 2314 & 41 & 40 \\
\hline $\operatorname{Re} 29.13$ & 178 & 3675 & 8 & 64 & $\operatorname{Re} 23.4$ & 124 & 892 & 0 & 65 & $\sigma$ & 30 & 3031 & 76 & 16 \\
\hline $\operatorname{Re} 29.16$ & 169 & 2473 & 0 & 56 & $\operatorname{Re} 23.6$ & 126 & 790 & 0 & 46 & & & & & \\
\hline $\operatorname{Re} 29.17$ & 171 & 3141 & 26 & 62 & $\operatorname{Re} 23.8$ & 137 & 705 & 0 & 39 & & & & & \\
\hline
\end{tabular}

Analyses were performed at the Department of Earth Sciences of the University of Oxford. $\sigma$ is standard deviation.

both studied sections exhibit the most-open marine facies, the thickest beds, and relatively negative $\delta^{13} \mathrm{C}$ and $\delta^{18} \mathrm{O}$ values (Fig. 3). The general decrease in the isotopic values from the base of the studied interval to the second-order MFD coincides with this long-term transgressive trend. The high-resolution Tethyan-toboreal correlation performed by Colombié \& Rameil (2007) shows that the second-order MFD in the Swiss Jura corresponds to a positive shift in $\delta^{13} \mathrm{C}$ (Fig. 6) in bulk organic matter from the Kimmeridge Clay Formation (KCF) of southern England (Morgans-Bell et al. 2001). However, the enhanced $\delta^{13} \mathrm{C}_{\mathrm{TOC}}$ values in the KCF mostly correlate with enhanced TOC values that probably result from enhanced preservation of carbohydrates through sulphurization (van Dongen, Schouten \& Sinninghe Damste, 2006). They are most likely caused by a longer duration of photic zone euxinia in the depositional environment and do not reflect the overall composition of dissolved inorganic carbon in seawater. Moreover, whatever the palaeogeographical location (boreal or Tethyan), the Late Kimmeridgian is characterized by either an increase or a decrease in carbon- and oxygen-isotope ratios (Morgans-Bell et al. 2001; Weissert \& Mohr, 1996; Jenkyns et al. 2002; Bartolini, Baumgartner \& Guex, 1999; Bartolini, Baumgartner \& Hunziker, 1996; Cecca et al. 2001; Gröcke et al. 2003; Morettini et al. 2002; Padden et al. 2002; Price \& Gröcke, 2002; Price \& Rogov, 2009; Riboulleau et al. 1998; Wierzbowski, 2004). Lastly, the compilation of $\delta^{18} \mathrm{O}$ and $\delta^{13} \mathrm{C}$ values from diagenetically little altered Phanerozoic fossil shells indicates a general decrease in $\delta^{18} \mathrm{O}$ and $\delta^{13} \mathrm{C}$ 


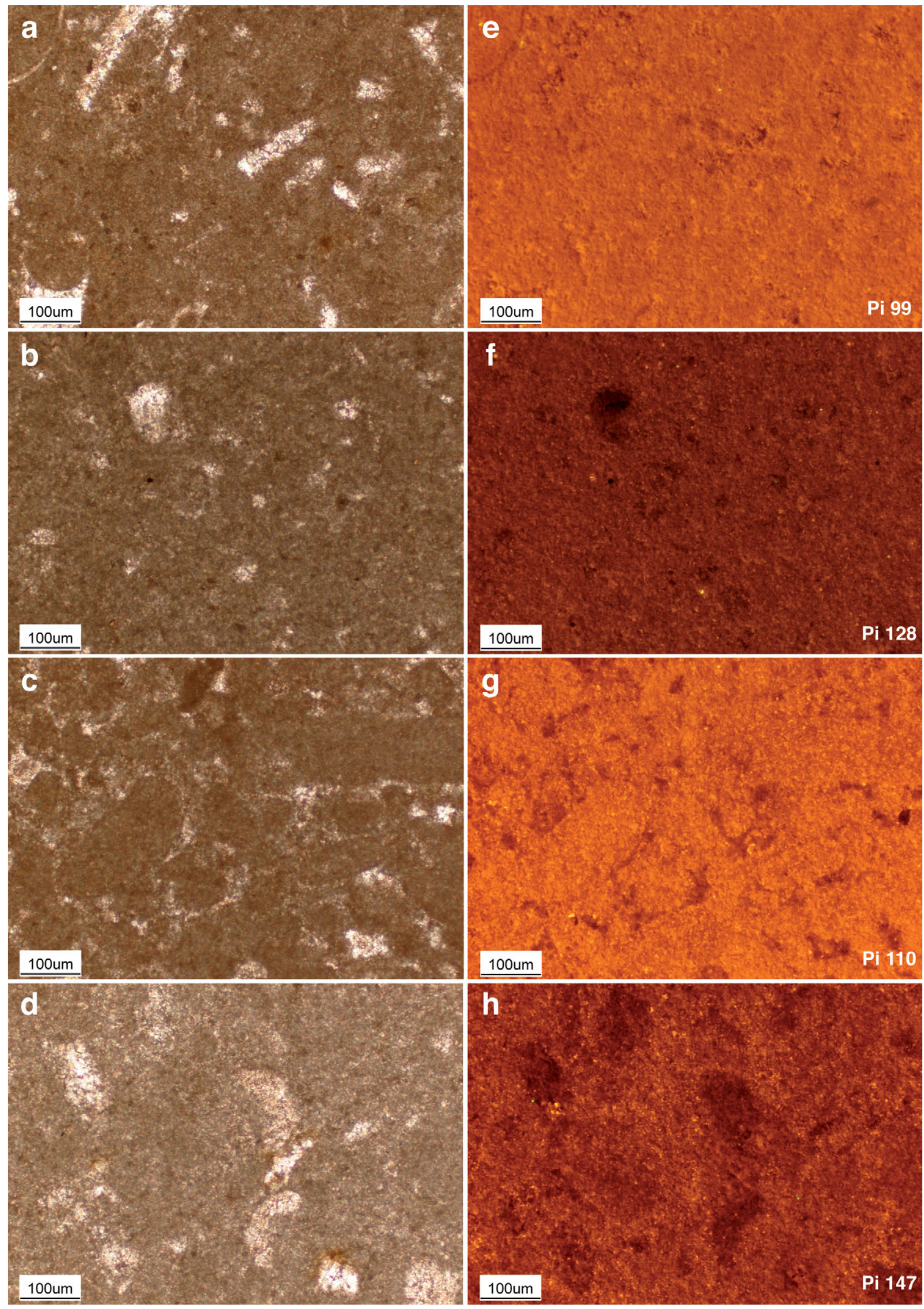

Figure 5. Plain light ( $\mathrm{a}, \mathrm{b}, \mathrm{c}, \mathrm{d})$ and cathodoluminescence (e, f, g, h) photomicrographs of samples Pi 99 (a, e), and Pi 128 (b, f) characterizing transgressive deposits, and Pi $110(\mathrm{c}, \mathrm{g})$, and Pi $147(\mathrm{~d}, \mathrm{~h})$ representing maximum-flooding deposits of the Gorges du Pichoux section. Most samples are fine-grained micrites and show yellow to orange and orange to red homogeneous luminescence, which indicates that the studied samples have undergone diagenetic alteration. 


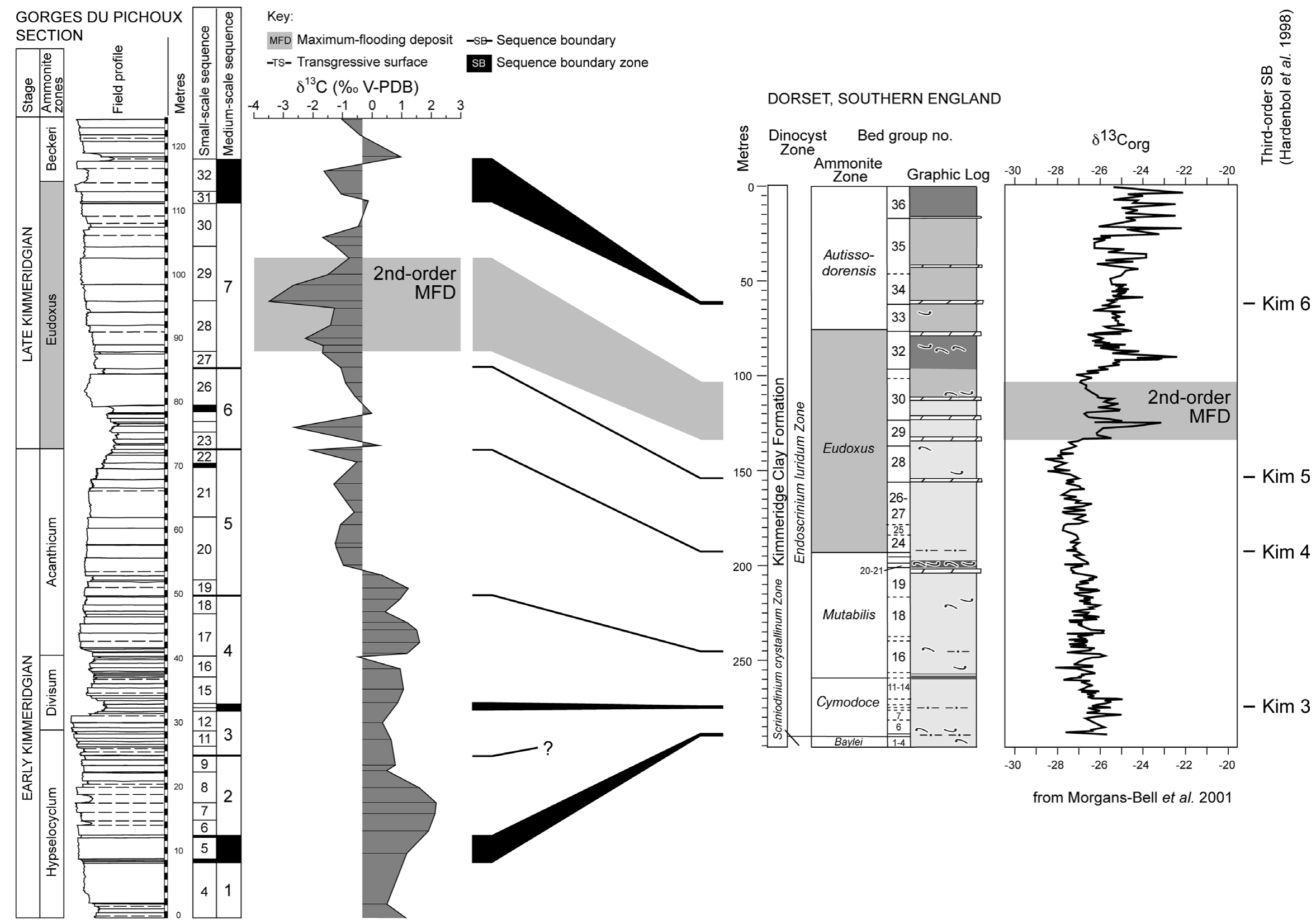

Figure 6. Correlation of carbon-isotope ratio variations between the Swiss Jura and the lower part of the Kimmeridge Clay Formation in southern England according to Colombié \& Rameil (2007) The second-order MFD in the Gorges du Pichoux section, which shows the lowest $\delta^{13} \mathrm{C}$ values, coincides with a positive shift in $\delta^{13} \mathrm{C}$ in the Kimmeridge Clay Formation of southern England. Carbonand oxygen-isotopic composition increases or decreases in the Late Kimmeridgian depending on geographical location, suggesting that high-resolution variations in $\delta^{13} \mathrm{C}$ values in the Swiss Jura partly result from diagenetic alteration or changes in local environmental conditions. 


\begin{tabular}{|c|c|c|c|c|c|}
\hline \multicolumn{3}{|c|}{$\begin{array}{l}\text { Controls on } \delta^{18} \mathrm{O} \text { and } \delta^{13} \mathrm{C} \text { of } \\
\mathrm{ABIOTIC/BIOTIC} \text { carbonates }\end{array}$} & REFERENCES & $\delta^{18} \mathrm{O}$ & $\delta^{13} \mathrm{C}$ \\
\hline \multirow{8}{*}{ 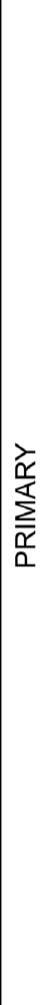 } & \multirow{2}{*}{ 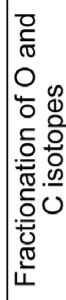 } & \begin{tabular}{|c|} 
PRECIPITATION OF \\
CARBONATES \\
mineralogy \\
increasing temperature \\
increasing $\mathrm{pH}$
\end{tabular} & $\begin{array}{l}\text { Patterson \& Walter, 1994a; Romanek, } \\
\text { Grossman \& Morse, 1992; Swart \& Eberli, } \\
\text { 2005; Zeebe, } 1999\end{array}$ & $\frac{+}{-}$ & + \\
\hline & & $\begin{array}{l}\text { VITAL EFFECTS } \\
\text { kinetic effects }\end{array}$ & $\begin{array}{l}\text { Auclair, Joachimski \& Lécuyer, 2003; Auclair } \\
\text { et al. 2004; McConnaughey, 1989a; McCon- } \\
\text { naughey, 1989b }\end{array}$ & 一 & - \\
\hline & \multirow{6}{*}{ 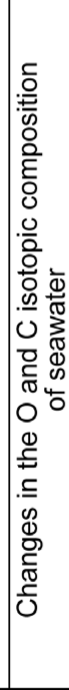 } & freshwater discharge & Patterson \& Walter, 1994a & - & - \\
\hline & & $\begin{array}{l}\text { VITAL EFFECTS } \\
\text { metabolic effects } \\
\text { respiration } \\
\text { photosynthesis }\end{array}$ & $\begin{array}{l}\text { Auclair, Joachimski \& Lécuyer, 2003; Auclair } \\
\text { et al. 2004; Lloyd, 1962; McConnaughey, } \\
\text { 1989a; McConnaughey et al. 1997; Patterson } \\
\text { \& Walter, 1994a }\end{array}$ & & $\overline{+}$ \\
\hline & & $\begin{array}{l}\text { organic matter oxidation } \\
\text { organic matter production } \\
\text { and burial }\end{array}$ & Joachimski, 1994; Lloyd, 1962 & & $\begin{array}{l}- \\
+\end{array}$ \\
\hline & & $\begin{array}{l}\text { carbonate precipitation } \\
\text { carbonate dissolution }\end{array}$ & & & $\begin{array}{l}- \\
+\end{array}$ \\
\hline & & evaporation & Patterson \& Walter, 1994a & + & \\
\hline & & water mass "ageing" & $\begin{array}{l}\text { Gomez et al. 2007; Holmden et al. 1998; } \\
\text { Lloyd, 1962; Panchuk, Holmden \& Kump, } \\
\text { 2005; Panchuk, Holmden \& Leslie, 2006; } \\
\text { Patterson \& Walter 1994a }\end{array}$ & & - \\
\hline \multirow{3}{*}{ 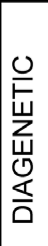 } & & & $\begin{array}{l}\text { Panchuk, Holmden \& Leslie, 2006; Patterson } \\
\text { \& Walter, 1994b }\end{array}$ & + & + \\
\hline & & early meteoric diagenesis & $\begin{array}{l}\text { Allan \& Matthews, 1982; Brand \& Veizer, } \\
\text { 1981; Immenhauser et al. 2002; Immenhauser } \\
\text { et al. 2003; Joachimski, 1994; Lohmann, } \\
\text { 1988; Moore, 2001; Veizer et al. } 1999\end{array}$ & - & - \\
\hline & & burial diagenesis & Moore, 2001 & - & + \\
\hline
\end{tabular}

Figure 7. Primary and diagenetic controls on $\delta^{13} \mathrm{C}$ and $\delta^{18} \mathrm{O}$ values of abiotic and biotic carbonates according to the references listed in this figure, but see also Immenhauser, Holmden \& Patterson (2007), Marshall (1992), Anderson \& Arthur (1983), Scholle \& Arthur (1980) and Zeebe \& Wolf-Gladrow (2001). Primary oxygen- and carbon-isotopic composition of carbonates depends on fractionation of oxygen and carbon isotopes during precipitation of carbonates or kinetic vital effects, or changes of the oxygen- and carbon-isotopic composition of seawater.

values during the Late Jurassic (Prokoph, Shields \& Veizer, 2008; Veizer et al. 1999). At $150 \mathrm{Ma}$, which is approximately the age of the studied interval, mean $\delta^{18} \mathrm{O}$ and $\delta^{13} \mathrm{C}$ values were $-0.75 \%$ and $1.7 \%$, respectively (Veizer et al. 1999). More recently, Prokoph, Shields \& Veizer (2008) gave $-1.5 \%$ for $\delta^{18} \mathrm{O}$ and $2.8 \%$ for $\delta^{13} \mathrm{C}$ of brachiopods. These values are consistent with those measured by Riboulleau et al. (1998) and Wierzbowski (2004) from belemnite rostra: $\delta^{18} \mathrm{O}$ and $\delta^{13} \mathrm{C}$ values varied from -1.8 to $0 \%$ and from -1.5 to $3 \%$, respectively. Most of these values are higher than the mean $\delta^{18} \mathrm{O}$ and $\delta^{13} \mathrm{C}$ values presented here (that is, -4.6 and $0 \%$, respectively).

Consequently, the general decrease in the carbonand oxygen-isotopic ratios from the base of the studied interval to the second-order MFD coincides with secular changes that are expressed also on a more global scale. However, both studied sections show lower values than those measured from contemporaneous shell or whole rock samples in other basins, and highfrequency changes in $\delta^{13} \mathrm{C}$ and $\delta^{18} \mathrm{O}$ values that are superimposed on the general decrease in carbon- and oxygen-isotopic compositions.

Controls on the $\delta^{13} \mathrm{C}$ and $\delta^{18} \mathrm{O}$ values of abiotic and biotic carbonates are numerous (Fig. 7). In the following, diagenetic effects and environmental conditions will be discussed.

\section{5.b. Diagenetic alteration}

Both petrography and geochemistry can be used to detect diagenetic products (Marshall, 1992; Moore, 2001). Cement type can be diagnostic of a particular diagenetic environment. However, identical cement types may be formed in different diagenetic environments. For example, equant drusy spar cement may precipitate in near-surface meteoric environments and under deep burial conditions (Flügel, 2004). 
Moreover, most samples from the Kimmeridgian of the Swiss Jura are fine-grained micrites, in which cementation and diagenetic alteration are difficult to identify using transmitted light microscopy (Fig. 5). Therefore, attention must be paid to isotopes, trace elements and cathodoluminescence fabrics to correctly interpret the diagenetic environment.

Only early meteoric diagenesis leads to concomitant decreases in ${ }^{18} \mathrm{O}$ and ${ }^{13} \mathrm{C}$ contents of carbonates (Fig. 7) and could explain the low $\delta^{13} \mathrm{C}$ and $\delta^{18} \mathrm{O}$ values measured in the Kimmeridgian of the Swiss Jura. The oxygen- and carbon-isotopic compositions of meteoric cements will depend on the isotopic composition of the meteoric waters invading the sediment. The oxygenisotopic composition of meteoric waters is strongly latitude dependent and can vary in $\delta^{18} \mathrm{O}$ from -20 to $-2 \%$ SMOW (Anderson \& Arthur, 1983; Hudson, 1977). At any specific geographic site, however, the initial $\delta^{18} \mathrm{O}$ composition of meteoric water should be relatively constant. In most meteoric environments, the prime source for the ultimate carbon-isotopic composition of meteoric diagenetic waters is soil gas and the $\mathrm{CO}_{2}$ derived from the dissolution of marine limestones (Allan \& Matthews, 1982; Lohmann, 1988). Equilibration with organically derived $\mathrm{CO}_{2}$ with a strongly negative $\delta^{13} \mathrm{C}(-25$ to $-16 \%$ o) depends on the extent of rock-water interaction. The pattern of invariant $\delta^{18} \mathrm{O}$ combined with variable $\delta^{13} \mathrm{C}$, termed the meteoric calcite line, serves as the baseline relative to which chemical variations characteristic of vadosephreatic, mixed-water and spelean environments can be discriminated (Lohmann, 1988). Trace, minor and major cations are also mobilized as carbonate rock is progressively altered. Post-depositional alteration therefore leads to increases in $\mathrm{Mn}^{2+}$ and $\mathrm{Fe}^{2+}$ contents, and decreases in $\mathrm{Sr}^{2+}, \mathrm{Na}^{+},{ }^{18} \mathrm{O}$ and possibly ${ }^{13} \mathrm{C}$ contents in carbonate components (Brand \& Veizer, 1981). $\mathrm{Sr}^{2+}$ and $\mathrm{Mn}^{2+}$ are useful diagenetic tracers because of their widely divergent partition coefficients, their association mostly with the carbonate lattice, and their large compositional differences in marine and meteoric water (Bodine, Holland \& Borcsik, 1965; Kinsman, 1969; Turekian, 1972).

Oxygen-isotope values range from -6.7 to $-2 \%$ o in the Gorges du Pichoux section and from -8.7 to $-2.2 \%$ in the Péry-Reuchenette section (Table 1). They are lower than the literature estimates of Kimmeridgian marine carbonates, which vary between -1.85 and $0 \%$ (Riboulleau et al. 1998; Wierzbowski, 2004). However, carbon-isotope values range between -3.5 and $2.2 \%$ in the Gorges du Pichoux section, and between -2 and $3.1 \%$ in the Péry-Reuchenette section (Table 1). These values are close to the $\delta^{13} \mathrm{C}$ values from Kimmeridgian marine carbonates, which range from -1.5 to $3 \%$ (Riboulleau et al. 1998; Wierzbowski, 2004). Low $\delta^{18}$ O values, moreover, do not coincide with low $\delta^{13} \mathrm{C}$ values (except for sample Pi 217). Furthermore, slopes of $\left(\delta^{13} \mathrm{C}, \delta^{18} \mathrm{O}\right)$ correlation lines range from 0.78 for the whole Gorges du Pichoux section to 1.86 for the lower part of the PéryReuchenette section (Fig. 4), suggesting that carbonand oxygen-isotope ratios were modified in the same way. Lastly, $\delta^{18} \mathrm{O}$ values and $\mathrm{Sr}$ contents are related in the Gorges du Pichoux section, while they are two independent variables in the Péry-Reuchenette section (Fig. 8).

Changes through time in $\delta^{18} \mathrm{O}$ and $\delta^{13} \mathrm{C}$ values are similar in both studied sections. Increases in $\delta^{18} \mathrm{O}$ and $\delta^{13} \mathrm{C}$ values in TD and decreases in MFD occur in two large-scale sequences. That meteoric diagenesis can have a strong influence at low relative sea level (that is, around sequence boundaries) seems only logical. However, the slopes of $\left(\delta^{13} \mathrm{C}, \delta^{18} \mathrm{O}\right)$ correlation lines are 0.77 for TD and 0.53 for MFD (Fig. 9). These slopes are in accordance with those defined for the whole studied sections and their lower and upper parts (Fig. 4). Therefore, the measured isotopic signals do not imply a stronger influence of meteoric diagenesis in the shallower-water facies of TD. Also, it is difficult to conceive that meteoric diagenesis could have dominated the deeper-water facies of MFD. Lastly, the absence of pronounced subaerial exposure surfaces excludes the possibility of long-lasting and pervasive freshwater lenses affecting thick portions of the sedimentary record.

Strontium contents in the Gorges du Pichoux and Péry-Reuchenette sections (Tables 2,3 ) are very low compared to $\mathrm{Sr}$ contents of modern micrites (Kinsman, 1969; Andrews, Christidis \& Dennis, 1997; Bosence, 1995; Gischler \& Zingeler, 2002; Milliman et al. 1993). However, manganese contents are close to those of modern lagoonal (brackish water) or freshwater carbonate sediments (Friedman, 1969), and lower than those measured in pelagic carbonates of Kimmeridgian successions (de Rafélis et al. 2000). In addition, (Sr, $\mathrm{Mn}$ ) scatter diagrams performed for the Gorges du Pichoux and Péry-Reuchenette sections do not show any relationship between $\mathrm{Sr}$ and $\mathrm{Mn}$ contents (Fig. 8), and the same is true for the ( $\mathrm{Sr}, \mathrm{Mn})$ distribution covering only the TD and MFD (Fig. 9).

Cathodoluminescence microscopy was applied to check diagenetic effects. $\mathrm{Mn}^{2+}$ is considered as the main activator of an orange-coloured luminescence, while $\mathrm{Fe}^{2+}$ acts as an inhibitor resulting in a dark red (dull) or no luminescence (Joachimski et al. 2005; Machel et al. 1991; Savard, Veizer \& Hinton, 1995). Since $\mathrm{Mn}^{2+}$ is only soluble under reducing conditions, the observed orange-coloured luminescence is indicative of diagenetic stabilization under non-oxidizing conditions (probably marine burial to burial) (van Geldern et al. 2006).

In conclusion, there is no clear evidence that meteoric diagenesis was not responsible for the low $\delta^{18} \mathrm{O}$ and $\delta^{13} \mathrm{C}$ values measured in the Kimmeridgian of the Swiss Jura. Moreover, cathodoluminescence microscopy indicates that the analysed samples have undergone diagenetic alteration that uniformly affected matrix and grains and was the 
a

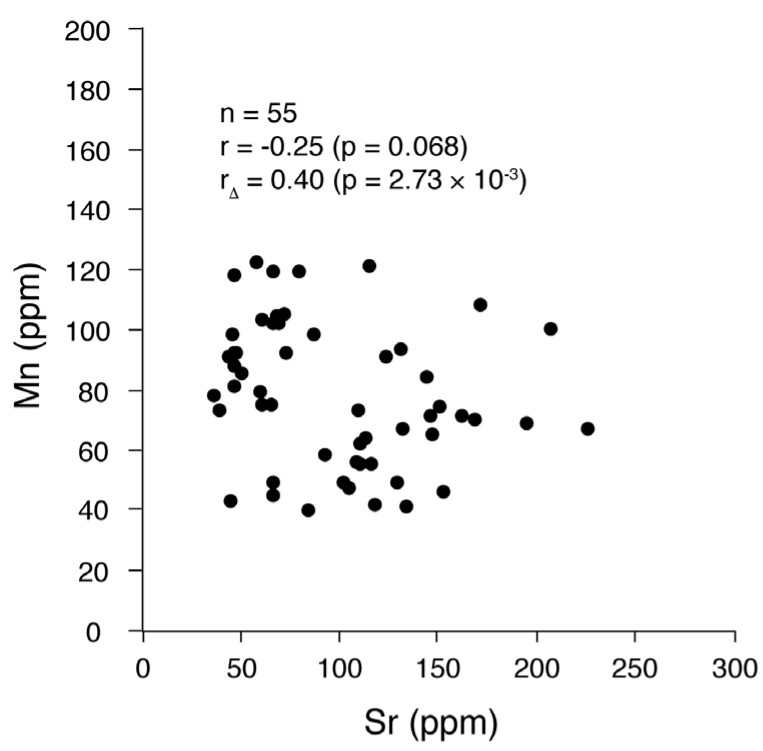

b

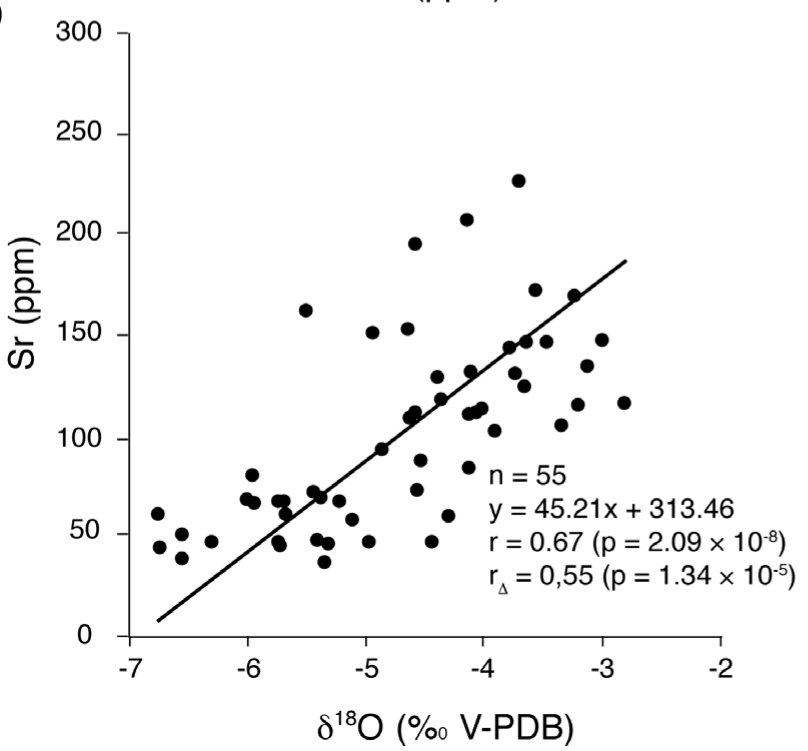

C

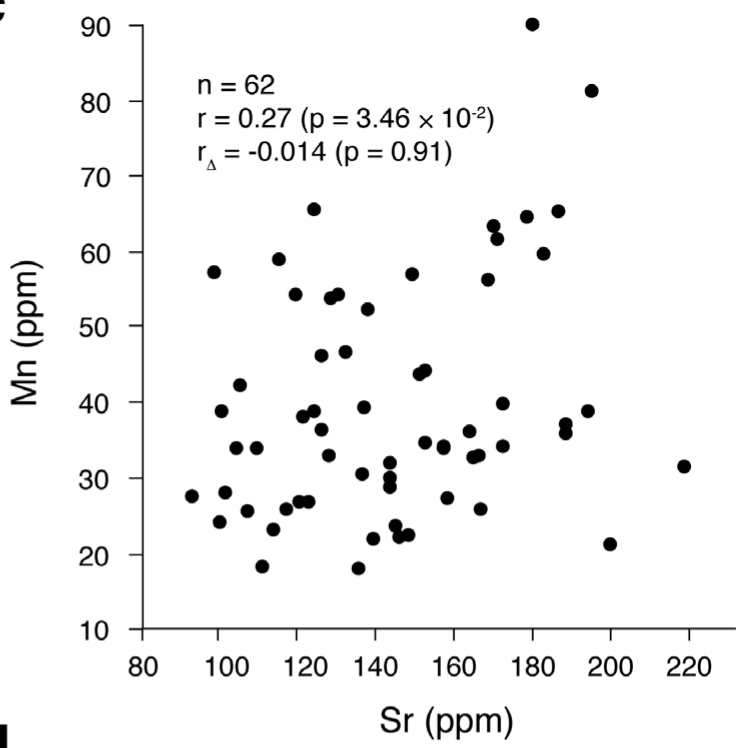

d

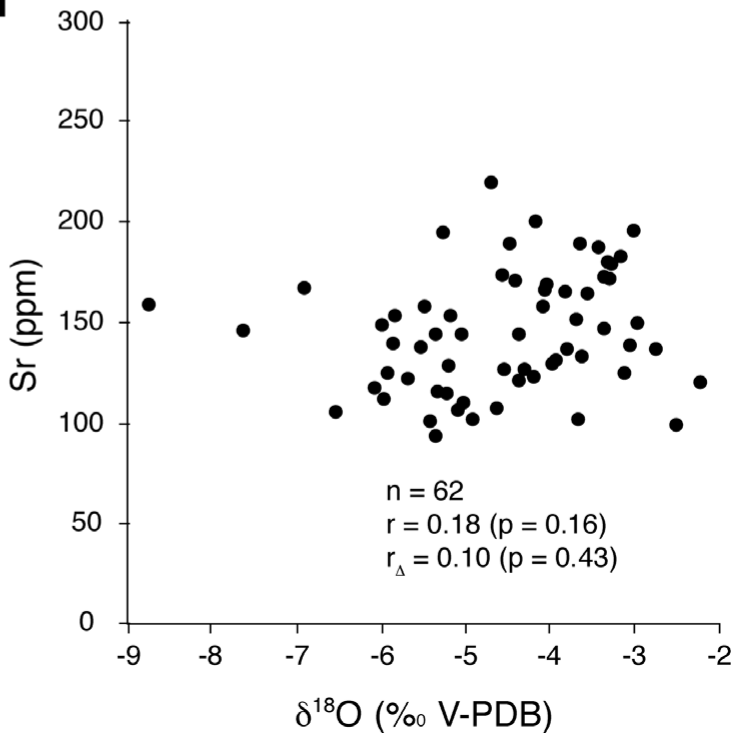

Figure 8. (Sr, Mn) and $\left(\delta^{18} \mathrm{O}, \mathrm{Sr}\right)$ scatter diagrams for the Gorges du Pichoux (a, b) and Péry-Reuchenette (c, d) sections. $\delta^{18} \mathrm{O}$ values and $\mathrm{Sr}$ contents correlate in the Gorges du Pichoux section, whereas they are two independent variables in the Péry-Reuchenette section, suggesting changes in diagenetic alteration from one section to the other.

same whatever the stratigraphic location of the studied samples.

\section{5.c. Changes in local environmental conditions}

Several controls lead to changes in the oxygen- and carbon-isotopic compositions of seawater that induce changes in the $\delta^{18} \mathrm{O}$ and $\delta^{13} \mathrm{C}$ values of carbonates (Fig. 7). However, only freshwater discharge results in concomitant decreases in oxygen- and carbonisotopic compositions of carbonates. Dilution by freshwater lowers both $\delta^{13} \mathrm{C}$ and $\delta^{18} \mathrm{O}$ values of seawater from which marine carbonates precipitate because of depletion in ${ }^{13} \mathrm{C}$ and ${ }^{18} \mathrm{O}$ of freshwater relative to seawater (Patterson \& Walter, 1994a). The lower part of the studied sections locally shows gyrogonites and stems of charophytes in bioturbated mudstones with fossils of euryhaline organisms (ostracodes, bivalves, miliolids). These deposits indicate ponds between channel systems that became brackish during periods of heavy rainfall (Colombié \& Strasser, 2005). However, the decreasing kaolinite-to-illite ratio and quartz content, the disappearance of charophytes, and the appearance of gypsum pseudomorphs in the upper part of the studied sections indicate that climate changed from more humid to more arid at the boundary between the Early and Late Kimmeridgian (Colombié, 2002). Freshwater runoff most likely decreased from Early to Late Kimmeridgian times while salinity increased, leading to gypsum formation in the most restricted areas. Therefore, the low $\delta^{18} \mathrm{O}$ and $\delta^{13} \mathrm{C}$ values measured and the high-frequency changes in oxygen- and carbon-isotopic compositions observed in the Kimmeridgian of the Swiss Jura rather result from the combination of multiple factors probably controlled by high-frequency changes in 

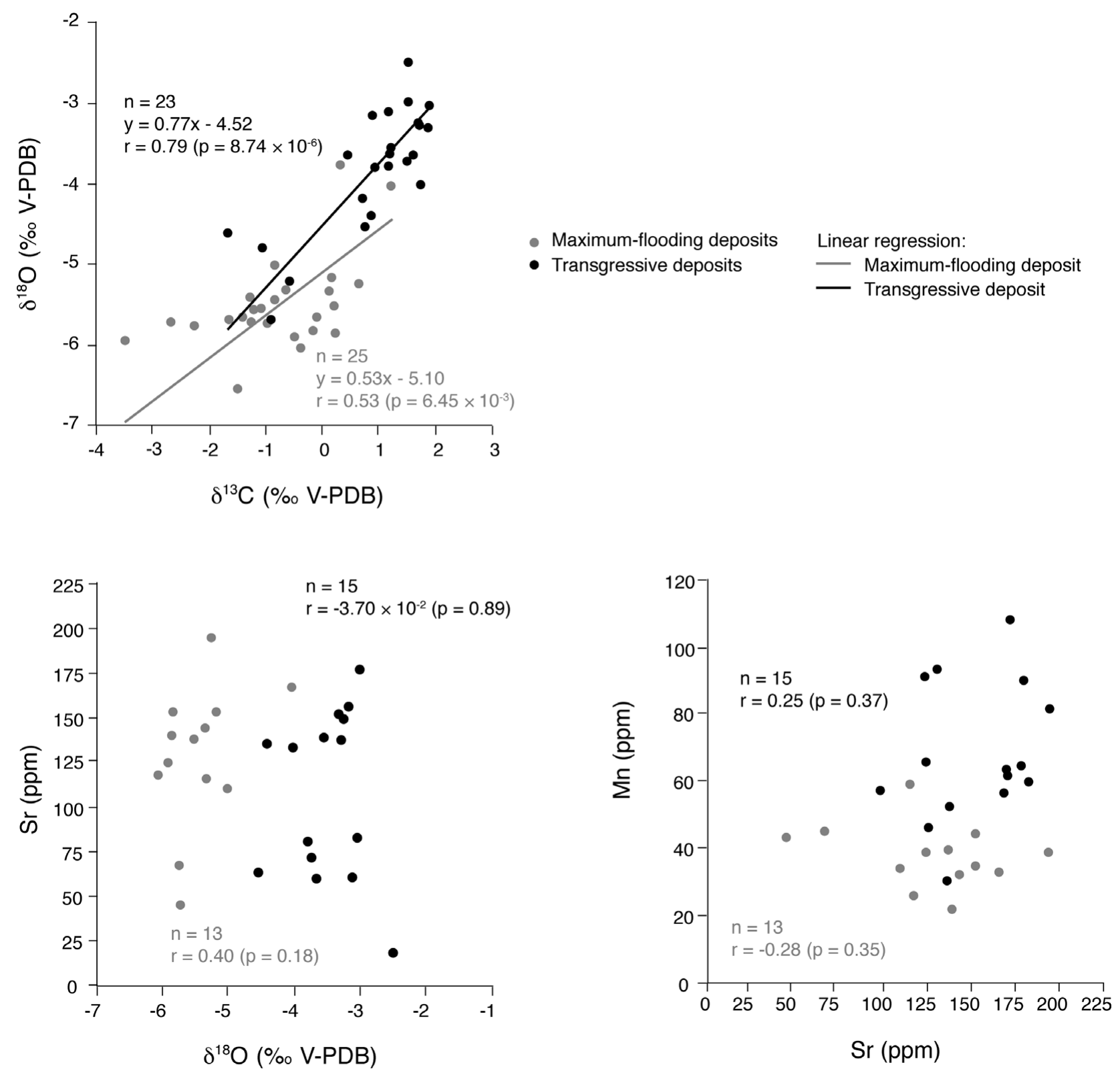

Figure 9. $\left(\delta^{13} \mathrm{C}, \delta^{18} \mathrm{O}\right),\left(\delta^{18} \mathrm{O}, \mathrm{Sr}\right)$ and $(\mathrm{Sr}, \mathrm{Mn})$ scatter diagrams for large-scale transgressive (TD) and maximum-flooding (MFD) deposits. Slopes of correlation lines are in accordance with those defined for the whole and the lower and the upper parts of the studied sections. Strontium contents and $\delta^{18} \mathrm{O}$, and $\mathrm{Sr}$ and $\mathrm{Mn}$ contents correlate neither in TD nor in MFD. The impact of diagenesis does not seem stronger in TD that are, however, shallower and more prone to diagenetic alteration than MFD.

relative sea level rather than from freshwater run-off alone.

Changes in $\delta^{13} \mathrm{C}$ and $\delta^{18} \mathrm{O}$ values measured in the Kimmeridgian of the Swiss Jura coincide with largescale changes in relative sea level. Relative sea-level changes are interpreted from the evolution through time of depositional environments and bed thicknesses (Colombié, 2002; Colombié \& Strasser, 2005). In a depositional sequence, the MFD correspond to the most open-marine depositional environments and to the thickest beds, which suggest the highest accommodation gain and carbonate accumulation (Colombié, 2002; Colombié \& Strasser, 2005). They also coincide with decrease in $\delta^{13} \mathrm{C}$ and $\delta^{18} \mathrm{O}$ values.

During the Kimmeridgian, the Swiss Jura platform was characterized by tidal flats and by more or less open-marine lagoons with shoals and bioherms (Colombié \& Strasser, 2005). An analysis of covariance shows that $\left(\delta^{13} \mathrm{C}, \delta^{18} \mathrm{O}\right)$ correlation lines, defined for each depositional environment, are parallel (Fig. 10; Table 4), suggesting that carbon- and oxygen-isotope fractionations between carbonates and seawater were the same in each environment. $\left(\delta^{13} \mathrm{C}, \delta^{18} \mathrm{O}\right)$ correlation lines defined for marsh, intertidal and open lagoonal environments in the Péry-Reuchenette section are parallel to the others (Fig. 10). However, a t-test applied to these data indicates that the corresponding $\delta^{13} \mathrm{C}$ and $\delta^{18} \mathrm{O}$ values are not interrelated (Table 4). This result is most likely due to scant data concerning these environments. The slopes of $\left(\delta^{13} \mathrm{C}, \delta^{18} \mathrm{O}\right)$ correlation lines range from 0.34 to 1.19 . These values are in accordance with those that were defined for the 

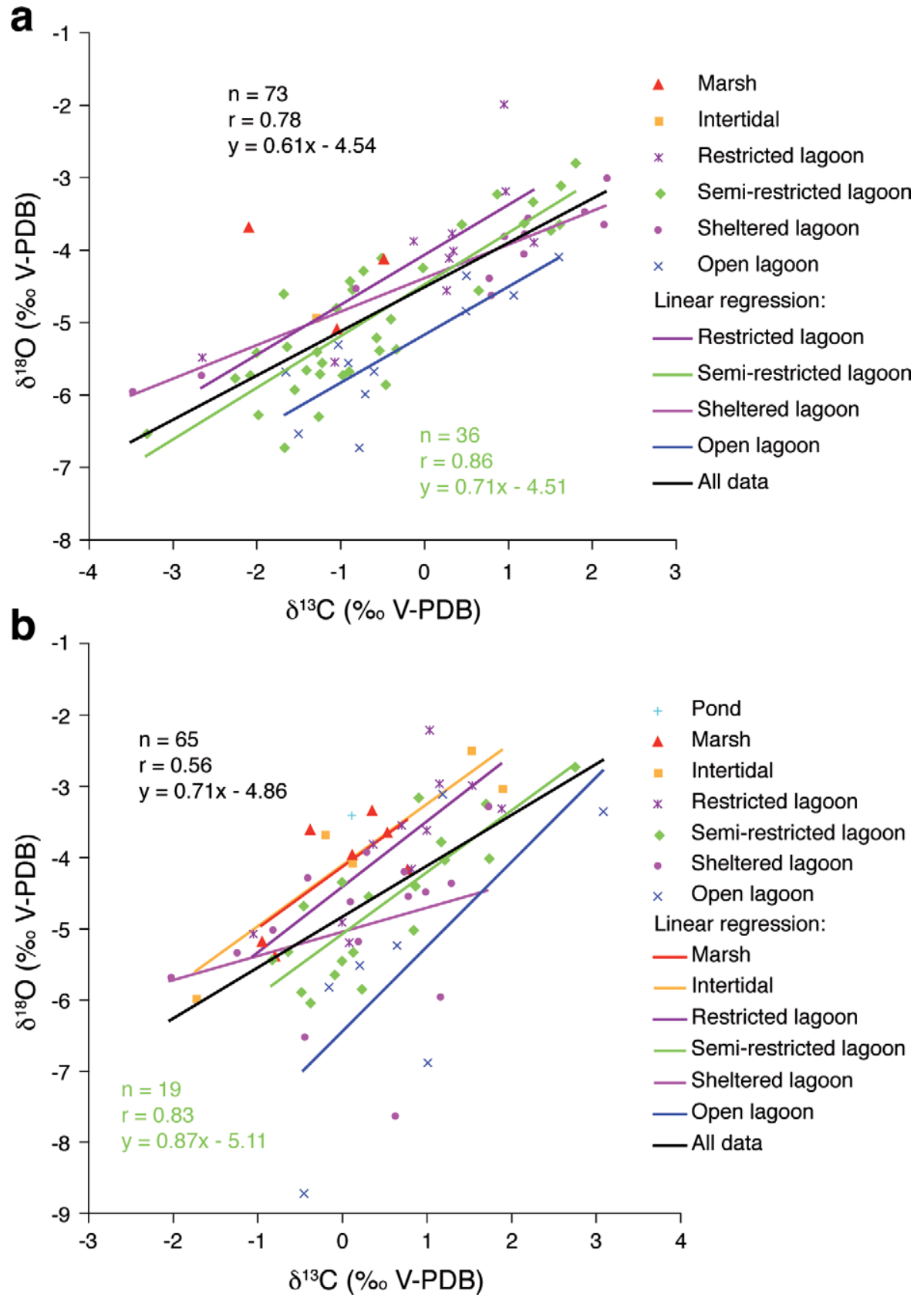

Figure 10. $\left(\delta^{13} \mathrm{C}, \delta^{18} \mathrm{O}\right)$ scatter diagrams showing regression lines defined for each environment of (a) the Gorges du Pichoux and (b) the Péry-Reuchenette sections. The $\left(\delta^{13} \mathrm{C}, \delta^{18} \mathrm{O}\right)$ regression lines defined for each depositional environment are parallel, suggesting that carbon- and oxygen-isotope fractionation is the same whatever the environment. These lines, however, show different $y$ intercepts. This offset is probably due to water mass ageing that increases from more open-marine to more restricted environments.

whole studied sections and their lower and upper parts (Fig. 4).

For both studied sections, $\left(\delta^{13} \mathrm{C}, \delta^{18} \mathrm{O}\right)$ correlation lines, defined for each depositional environment, show similar slopes but different $y$ intercepts (Fig. 10). These intercepts increase from more open-marine to more restricted environments (Fig. 11). This offset is interpreted as resulting from water mass ageing that would increase towards more restricted environments. Water mass ageing describes the isolation from vigorous exchange and mixing with the ocean surface waters (Immenhauser, Holmden \& Patterson, 2007; Lloyd, 1962). Broecker \& Takahashi (1966) and Morse et al. (1984) analysed several parameters of water samples from Grand Bahama Bank. They showed that increase in water mass ageing leads to increasing salinity.

The facies model devised by Colombié (2002) and Colombié \& Strasser (2005) for the Kimmeridgian of the Swiss Jura implies that salinity increased from more open-marine to more restricted, hypersaline environments. In the more proximal Gorges du Pichoux section, $\delta^{18} \mathrm{O}, \mathrm{Sr}$ and $\mathrm{Na}$ are interrelated variables (Figs 7, 12). They all depend on salinity (Fritz \& Katz, 1972; Jaffrezo \& Renard, 1979; Land \& Hoops, 1973; Veizer, 1983). In this section, decrease in 
a

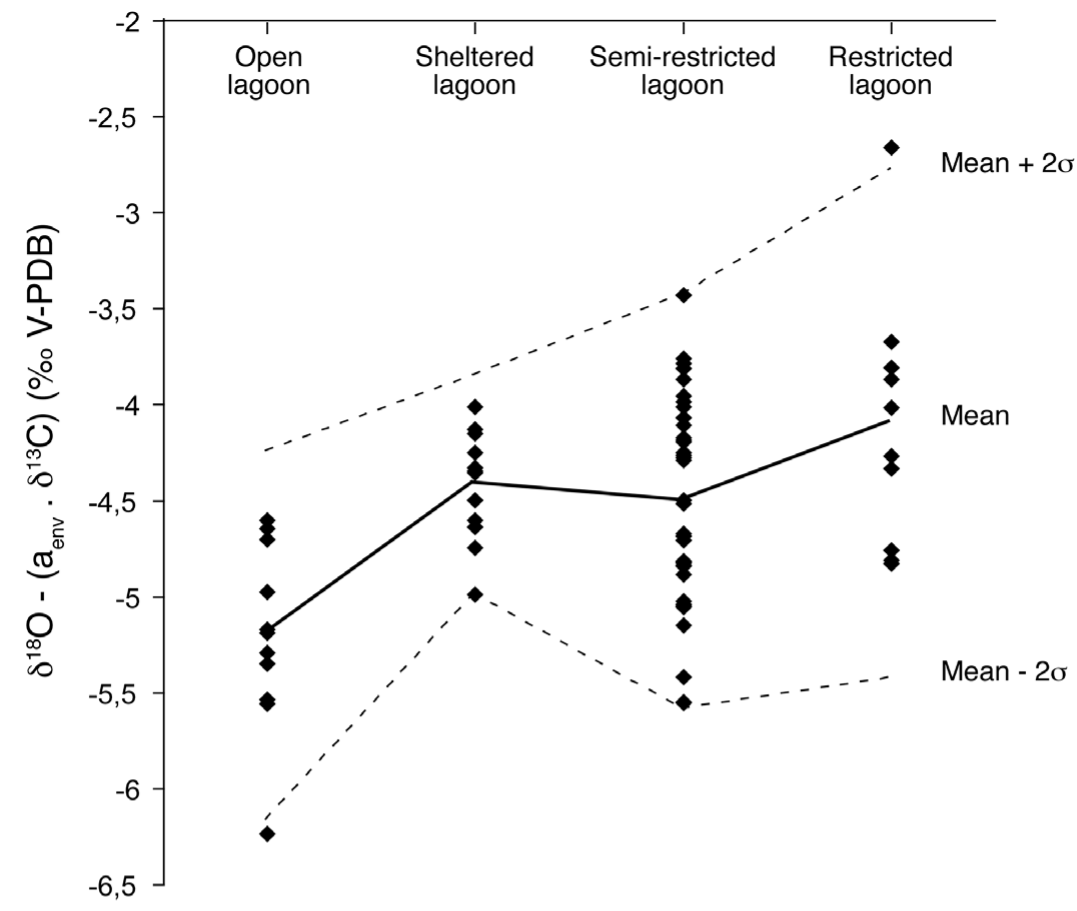

b

Depositional environments

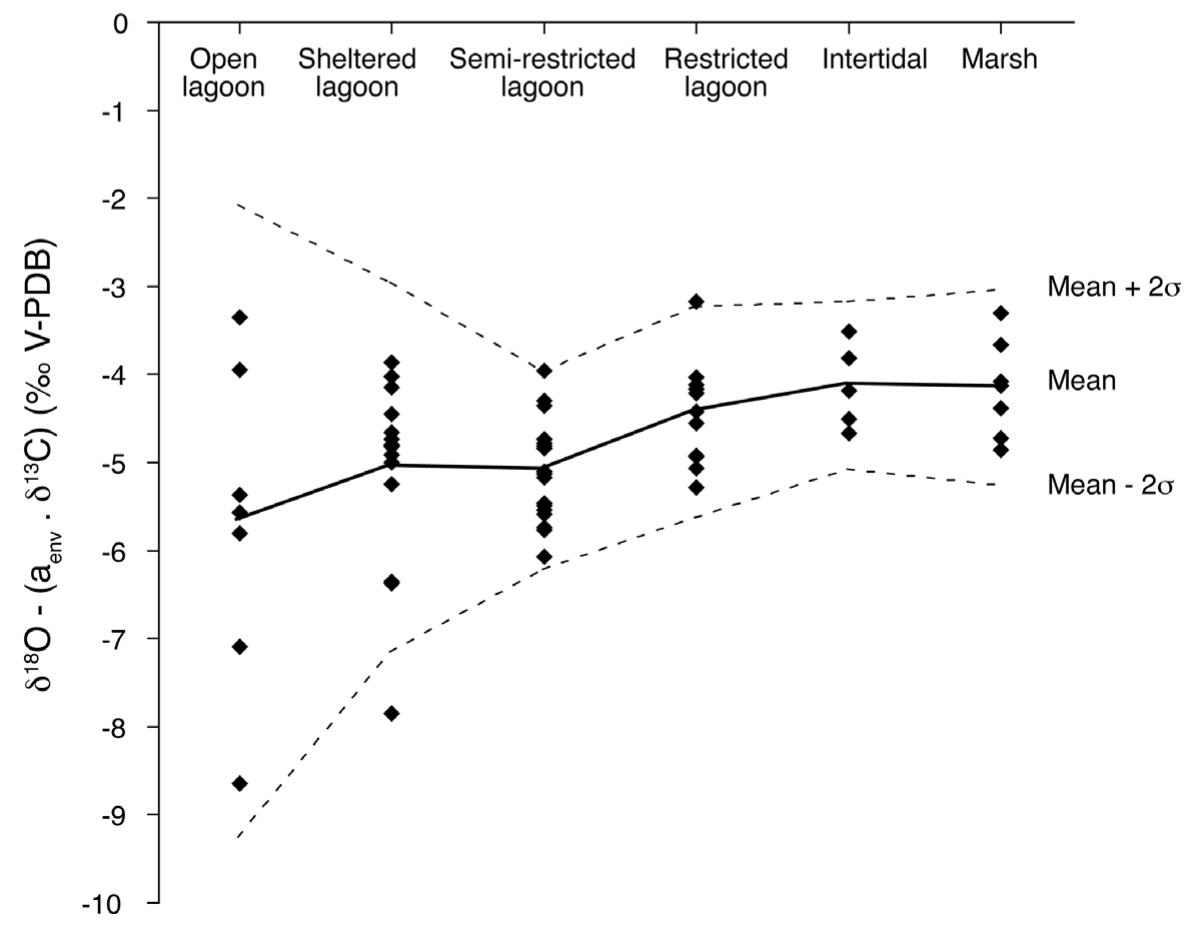

Figure 11. Rank correlation between $\delta^{18} \mathrm{O}-\left(\mathrm{a}_{\text {env }} \times \delta^{13} \mathrm{C}\right)$ values and depositional environments for the (a) Gorges du Pichoux and (b) Péry-Reuchenette sections. $\delta^{18} \mathrm{O}-\left(\mathrm{a}_{\text {env }} \times \delta^{13} \mathrm{C}\right)$ is the $y$ intercept, and $\mathrm{a}_{\text {env }}$ is the slope of the $\left(\delta^{13} \mathrm{C}, \delta^{18} \mathrm{O}\right)$ correlation lines that are defined for each depositional environment and listed in Table 4 . Area between dashed lines represents the $95 \%$ confidence belt. Almost all $y$ intercepts lie within this confidence belt, suggesting that the increase from more open-marine to more restricted environments is significant and depends on changes in palaeoenvironmental parameters. The Tau tests performed for the Gorges du Pichoux ( $\tau=0.307$; $\left.\mathrm{p}=1.9 \times 10^{-4}\right)$ and Péry-Reuchenette $\left(\tau=0.325 ; \mathrm{p}=1.5 \times 10^{-4}\right)$ sections confirm that $\delta^{18} \mathrm{O}$ values strongly depend on depositional environments.

$\delta^{18} \mathrm{O}$ during maximum-flooding conditions can thus be explained by normal salinity in an open-marine environment, when compared to higher salinity in more restricted conditions. In the Péry-Reuchenette section, however, $\delta^{18} \mathrm{O}$ and $\mathrm{Sr}$ are two independent variables (Fig. 8). Therefore, decreasing salinity alone cannot explain decreasing $\delta^{18} \mathrm{O}$ values during MFD in the Kimmeridgian of the Swiss Jura. 
Table 4. Statistical results for each depositional environment defined in the Gorges du Pichoux and Péry-Reuchenette sections

\begin{tabular}{lrclcc}
\hline & $\mathrm{n}$ & $\mathrm{r}$ & $\mathrm{p}(\mathrm{H} 0: \mathrm{r}=0)$ & $\mathrm{a}$ & $\mathrm{b}$ \\
\hline Gorges du Pichoux & & & & & \\
Restricted lagoon & 10 & 0.77 & $9.26 \times 10^{-3}$ & 0.69 & -4.10 \\
Semi-restricted lagoon & 36 & 0.86 & $2.38 \times 10^{-11}$ & 0.71 & -4.51 \\
Sheltered lagoon & 12 & 0.95 & $2.76 \times 10^{-6}$ & 0.46 & -4.42 \\
Open lagoon & 11 & 0.83 & $1.67 \times 10^{-3}$ & 0.66 & -5.20 \\
Péry-Reuchenette & & & & & \\
Marsh & 7 & 0.72 & 0.07 & 0.86 & -4.16 \\
Intertidal & 5 & 0.93 & 0.02 & 0.86 & -4.14 \\
Restricted lagoon & 11 & 0.78 & $4.64 \times 10^{-3}$ & 0.92 & -4.44 \\
Semi-restricted lagoon & 19 & 0.83 & $1.30 \times 10^{-5}$ & 0.87 & -5.11 \\
Sheltered lagoon & 15 & 0.31 & 0.25 & 0.34 & -5.07 \\
Open lagoon & 7 & 0.72 & 0.07 & 1.19 & -6.48 \\
\hline
\end{tabular}

$\mathrm{n}$ - number of observations, $\mathrm{r}$ - correlation coefficient, $\mathrm{a}$ - slope of regression line, $\mathrm{b}$ - intercept of regression line.

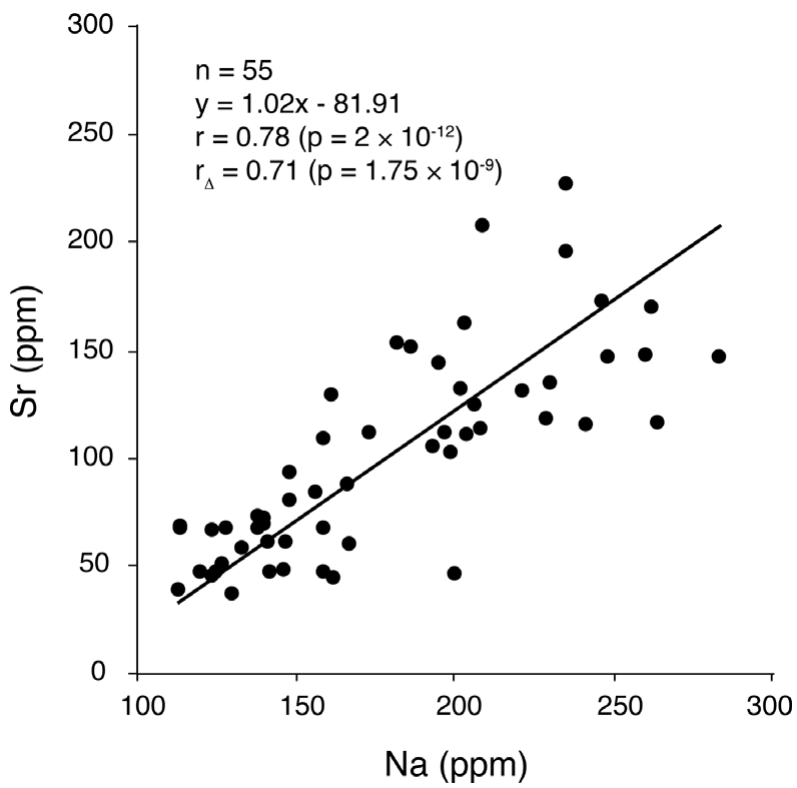

Figure 12. ( $\mathrm{Sr}, \mathrm{Na})$ scatter diagram for the Gorges du Pichoux section. The correlation between $\mathrm{Na}$ and $\mathrm{Sr}$ contents may be due to a control by salinity.

Broecker \& Takahashi (1966) and Morse et al. (1984) also indicated that the mean rate of carbonate precipitation decreases with increasing water mass ageing because the waters in the region of slower carbonate precipitation are substantially less supersaturated than in areas with a high precipitation rate. In the Kimmeridgian of the Swiss Jura, small-scale sequences took $100 \mathrm{ka}$ to form (Colombié, 2002; Colombié \& Strasser, 2003, 2005). Changes in their thickness reflect variations in carbonate production and accumulation rates. The second and third large-scale MFD in the Gorges du Pichoux section correspond to increasing carbonate production and accumulation rates (Fig. 13). This increase in carbonate production and accumulation rates, which is due to an opening of the system, a better connection with the open ocean, and thus to decreasing water mass ageing, systematically coincides with decreasing $\delta^{13} \mathrm{C}$ values (Fig. 13). Consequently, changes in $\delta^{13} \mathrm{C}$ values in

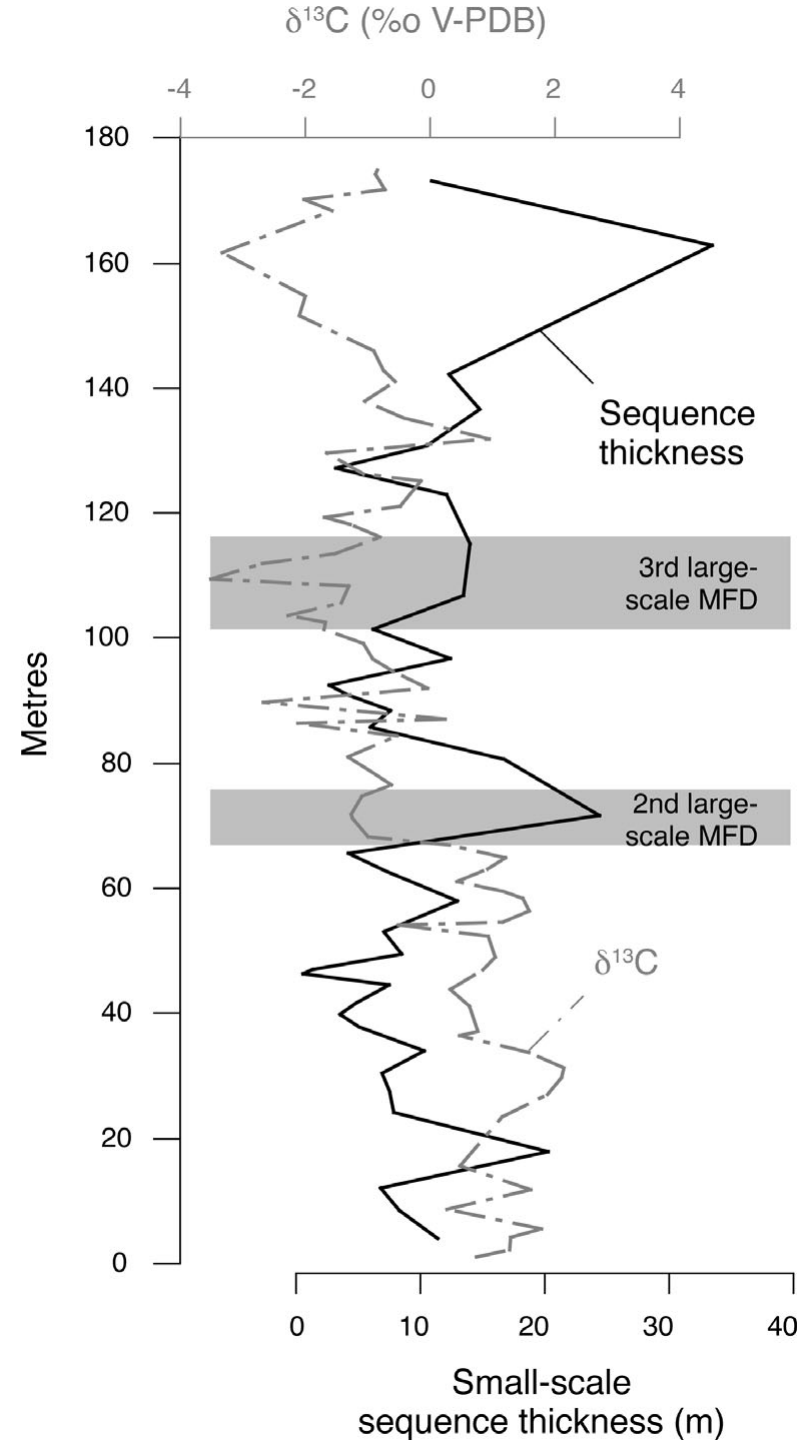

Figure 13. Changes in small-scale sequence thicknesses and $\delta^{13} \mathrm{C}$ values in the Gorges du Pichoux section. Small-scale sequences formed within $100 \mathrm{ka}$ (Colombié, 2002; Colombié \& Strasser, 2005), and changes in their thicknesses reflect variations in carbonate production and accumulation rates. In the second and third large-scale MFD, negative shifts in $\delta^{13} \mathrm{C}$ values correlate with positive shifts in sequence thicknesses, suggesting that increasing carbonate production and accumulation rates on the platform led to ${ }^{13} \mathrm{C}$ depletion in carbonates.

the Kimmeridgian of the Swiss Jura probably reflect changes in carbonate production and accumulation rates that may result from variations in residence time of waters on the platform.

Residence time of water masses, increasing with environmental restriction, may explain why $\delta^{13} \mathrm{C}$ and $\delta^{18} \mathrm{O}$ mean values and standard deviations are larger in the Gorges du Pichoux section, which is the more proximal section, than in the Péry-Reuchenette section, which is the more distal section (Fig. 3).

While the TD of the second large-scale sequence in both studied sections and the TD of the third largescale sequence in the Péry-Reuchenette section show a positive shift of $\delta^{13} \mathrm{C}$ values, the TD of the third large-scale sequence in the Gorges du Pichoux section 
is characterized by a negative shift of $\delta^{13} \mathrm{C}$ values (Fig. 3). This decrease in $\delta^{13} \mathrm{C}$ values coincides with an increase in carbonate production and accumulation rates (Fig. 13). This discrepancy can be explained by two separate water masses that covered the Jura platform at that time. Such compartmentalization may have been related to platform morphology, which was at least partly controlled by differential subsidence (Colombié, 2002). During highstand and lowstand conditions, compartmentalization was even more pronounced because water was generally shallower and the isolation of water bodies more likely. This explains the irregular pattern of the isotope curves in the corresponding deposits (Fig. 3).

\section{Conclusions}

Carbon- and oxygen-isotope analyses were performed on bulk shallow-marine carbonate samples coming from two Kimmeridgian sections located in the Swiss Jura. The comparison of the $\delta^{13} \mathrm{C}$ and $\delta^{18} \mathrm{O}$ records with the $\delta^{13} \mathrm{C}$ and $\delta^{18} \mathrm{O}$ records described from the same time interval in other basins, the use of trends in isotopic and trace-element data, as well as optical and cathodoluminescence petrography, and their combination with the sedimentological and sequence-stratigraphical interpretation of the two studied sections lead to the following conclusions:

(1) The general decrease in $\delta^{13} \mathrm{C}$ and $\delta^{18} \mathrm{O}$ values from the base to the top of the studied sections coincides with secular variations that are expressed on a more global scale. However, $\delta^{13} \mathrm{C}$ and $\delta^{18} \mathrm{O}$ values are lower than those measured from little-altered fossil shells, which reflect the general carbon- and oxygen-isotopic compositions of seawater at that time. Moreover, the Kimmeridgian carbonates of the shallow-water Jura platform show high-frequency changes in $\delta^{13} \mathrm{C}$ and $\delta^{18} \mathrm{O}$ values that are superimposed on the general trend.

(2) The generally more negative $\delta^{13} \mathrm{C}$ and $\delta^{18} \mathrm{O}$ values in the studied carbonates relative to those of the average Kimmeridgian ocean most probably result from a mix of diagenetic and local environmental effects.

(3) High-frequency changes in oxygen- and carbonisotopic compositions might result from variations in local environmental conditions on the shallow platform, which were different from those occurring in the open ocean. Variations in $\delta^{13} \mathrm{C}$ and $\delta^{18} \mathrm{O}$ are interpreted to be due to changes in salinity and carbonate production and accumulation rates that result from changes in residence time of water on the platform. Platform morphology and sea-level changes modified water circulation patterns and created water masses with distinct isotopic signatures.

(4) In shallow-marine carbonates, carbon- and oxygen-isotope records can be used as a tool for long-distance stratigraphic correlations only under the condition that the origin of the isotopic signals is well understood. The correlation of the studied sections with the Kimmeridge Clay Formation of southern England has demonstrated that coeval peaks in the isotope curves can be inversed due to diagenetic alteration and different local environmental conditions.

Acknowledgements. We thank two anonymous referees for constructive criticism. Financial support for this study came from the Swiss National Science Foundation (project no. 20-56491.99 and 81FR-68839) and the French CNRS program 'ECLIPSE II'. A great part of the analyses were performed during the $\mathrm{Ph} . \mathrm{D}$. and post-doctoral research of Claude Colombié. She thanks Steve Hesselbo, from the Department of Earth Sciences of the University of Oxford in England, who hosted her for a post-doctoral year, and for his constructive comments on the last version of this manuscript. Thanks go to Maureen Padden, to Julie Cartlidge, from the Department of Earth Sciences of the University of Oxford, and to François Martineau, from the UMR CNRS 5125 of the University of Lyon 1 in France, for carbonand oxygen-isotope analyses. Laurent Emmanuel, Benoît Vincent, and the technical staff from the University of Dijon in France and from the Department of Earth Sciences of the University of Oxford are acknowledged for trace element analyses. Thanks to Gilles Escarguel, Marie-Anne Héran and Arnaud Brayard for helping with statistical analyses. The constructive comments provided by Nicolas Olivier, Fabienne Giraud, Giovanni Aloisi, John Reijmer and Adrian Immenhauser greatly helped to improve an earlier version of this manuscript.

\section{References}

AbBinK, O., TARgarona, J., Brinkhuis, H. \& VISSCHER, H. 2001. Late Jurassic to earliest Cretaceous palaeoclimatic evolution of the southern North Sea. Global and Planetary Change 30, 231-56.

ABDI, H. 2007. Kendall rank correlation. In Encyclopedia of Measurement and Statistics (ed. N. J. Salkind), pp. 1-7. Thousand Oaks (CA): Sage.

AllAN, J. R. \& MATTHEWS, R. K. 1982. Isotope signatures associated with early meteoric diagenesis. Sedimentology 29, 797-817.

Anderson, T. F. \& Arthur, M. A. 1983. Stable isotopes of oxygen and carbon and their application to sedimentologic and paleoenvironemental problems. In Stable Isotopes in Sedimentary Petrology (eds M. A. Arthur, T. F. Anderson, J. Veizer \& L. S. Land), pp. 1-1 to 1-151. Dallas: SEPM Short Course.

Andrews, J. E., Christidis, S. \& Dennis, P. F. 1997. Assessing mineralogical and geochemical heterogeneity in the sub 63 micron size fraction of Holocene lime muds. Journal of Sedimentary Research 67, 531-5.

AUClair, A.-C., JOACHIMSKI, M. M. \& LÉCUYER, C. 2003. Deciphering kinetic, metabolic and environmental controls on stable isotope fractionations between seawater and the shell of Terebratalia transversa (Brachiopoda). Chemical Geology 202, 59-78.

Auclair, A.-C., LÉCuYer, C., Bucher, H. \& SHEPPARD, S. M. F. 2004. Carbon and oxygen isotope composition of Nautilus macromphalus: a record of thermocline waters off New Caledonia. Chemical Geology 207, 91-100.

Bartolini, A., Baumgartner, P. O. \& GueX, J. 1999. Middle and Late Jurassic radiolarian palaeoecology versus carbon-isotope stratigraphy. Palaeogeography Palaeoclimatology Palaeoecology 145, 43-60.

Bartolini, A., Baumgartner, P. O. \& Hunziker, J. 1996. Middle and Late Jurassic carbon stable-isotope 
stratigraphy and radiolarite sedimentation of the Umbria-Marche Basin (Central Italy). Eclogae geologicae Helvetiae 89, 811-44.

Bodine, M. W., Holland, H. D. \& Borcsik, M. 1965. Coprecipitation of manganese and strontium with calcite. In Symposium on Problems of Postmagmatic Ore Deposition, pp. 401-6. Prague.

BosenCE, D. W. J. 1995. Anatomy of a Recent biodetrital mud-mound, Florida Bay, USA. In Carbonate MudMounds: Their Origin and Evolution (eds C. L. V. Monty, D. W. J. Bosence, P. H. Bridges \& B. R. Pratt), pp. 439-73. Blackwell Science, International Association of Sedimentologists, Special Publication.

BRAND, U. \& VEIZER, J. 1980. Chemical diagenesis of a multicomponent carbonate system - 1: trace elements. Journal of Sedimentary Petrology 50, 1219-36.

BRAND, U. \& VEIZER, J. 1981. Chemical diagenesis of a multicomponent carbonate system - 2: stable isotopes. Journal of Sedimentary Petrology 51, 987-97.

BROECKER, W. S. \& TAKAHASHI, T. 1966. Calcium carbonate precipitation on the Bahama Bank. Journal of Geophysical Research 71, 1575-601.

Buonocunto, F. P., Sprovieri, M., Bellanca, A., D'Argenio, B., Ferreri, V., Neri, R. \& FerruzzA, G. 2002. Cyclostratigraphy and high-frequency carbon isotope fluctuations in Upper Cretaceous shallow-water carbonates, southern Italy. Sedimentology 49, 1321-37.

Cecca, F., Savary, B., Bartolini, A., Remane, J. \& CORDEY, F. 2001. The Middle Jurassic-Lower Cretaceous Rosso Ammonitico succession of Monte Inici (Trapanese domain, western Sicily): sedimentology, biostratigraphy and isotope stratigraphy. Bulletin de la Société géologique de France 172, 647-60.

Colombié, C. 2002. Sédimentologie, stratigraphie séquentielle et cyclostratigraphie du Kimméridgien du Jura suisse et du Bassin vocontien (France): relations plate-forme - bassin et facteurs déterminants. GeoFocus 5, $201 \mathrm{pp}$.

Colombié, C. \& RAMEIL, N. 2007. Tethyan-to-boreal correlation in the Kimmeridgian using high-resolution sequence stratigraphy (Vocontian Basin, Swiss Jura, Boulonnais, and Dorset). International Journal of Earth Sciences 96, 567-91.

Colombié, C. \& Strasser, A. 2003. Depositional sequences in the Kimmeridgian of the Vocontian Basin (France) controlled by carbonate export from shallowwater platforms. Geobios 36, 675-83.

Colombié, C. \& Strasser, A. 2005. Facies, cycles, and controls on the evolution of a keep-up carbonate platform (Kimmeridgian, Swiss Jura). Sedimentology 52, 1207-27.

DAVIS, J. C. 2002. Statistics and Data Analysis in Geology, $3 r d$ ed. John Wiley \& Sons.

De RAFÉlis, M., RenARD, M., EMmanuel, L. \& DuRlet, C. 2000. Apport de la cathodoluminescence à la connaissance de la spéciation du manganèse dans les carbonates pélagiques. Comptes Rendus de l'Académie des Sciences de Paris 330, 391-8.

ENOS, P. \& SAWATSKY, L. H. 1981. Pore networks in Holocene carbonate sediments. Journal of Sedimentary Petrology 51, 961-85.

FLÜGEL, E. 2004. Microfacies of carbonate rocks: analysis, interpretation and application. Springer.

FrIEDMAN, G. M. 1969. Trace elements as possible environmental indicators in carbonate sediments. In Depositional Environments in Carbonate Rocks (ed. G. M. Friedman), pp. 193-8. Tulsa, Oklahoma, USA: SEPM Special Publication.
FRITZ, P. \& KATZ, A. 1972. The sodium distribution of dolomite crystals. Chemical Geology 10, 237-44.

GISCHLER, E. \& ZINGELER, D. 2002. The origin of carbonate mud in isolated carbonate platforms of Belize, Central America. International Journal of Earth Sciences 91, 1054-70.

GlumaC, B. \& WALKer, K. R. 1998. A late Cambrian positive carbon-isotope excursion in the southern Appalachians: relation to biostratigraphy, sequence stratigraphy, environments of deposition, and diagenesis. Journal of Sedimentary Research 68, 1212-22.

Gomez, F. J., OGLe, N., Astini, R. A. \& Kalin, R. M. 2007. Paleoenvironmental and carbon-oxygen isotope record of Middle Cambrian carbonates (La Laja Formation) in the Argentine Precordillera. Journal of Sedimentary Research 77, 826-42.

Gröcke, D. R., Price, G. D., Ruffell, A. H., Mutterlose, J. \& BARABOSHKIN, E. 2003. Isotopic evidence for Late Jurassic-Early Cretaceous climate change. Palaeogeography Palaeoclimatology Palaeoecology 202, 97-118.

Grötsch, H. J., BILling, I. \& VAHRENKAMP, V. 1998. Carbon-isotope stratigraphy in shallow-water carbonates: implications for Cretaceous black-shale deposition. Sedimentology 45, 623-34.

GYGI, R. A. 1995. Datierung von Seichtwassersedimenten des Späten Jura in der Nordwestschweiz mit Ammoniten. Eclogae geologicae Helvetia 88, 1-58.

Gygi, R. A. \& Persoz, F. 1986. Mineralostratigraphy, litho- and biostratigraphy combined in correlation of the Oxfordian (Late Jurassic) formations of the Swiss Jura range. Eclogae geologicae Helvetiae 79, 385-454.

Hallam, A. 1984. Continental humid and arid zones during the Jurassic and Cretaceous. Palaeogeography Palaeoclimatology Palaeoecology 47, 195-223.

Hallam, A. 1985. A review of Mesozoic climates. Journal of the Geological Society, London 142, 433-45.

Hardenbol, J., Thierry, J., FARley, M. B., JacQuin, T., De Graciansky, P.-C. \& Vail, P. R. 1998. Jurassic chronostratigraphy. In Mesozoic and Cenozoic Sequence Stratigraphy of European Basins (eds P.-C. de Graciansky, J. Hardenbol, T. Jacquin \& P. R. Vail). SEPM Special Publication no. 60.

Holmden, C., Creaser, R. A., Muehlenbachs, K., Leslie, S. A. \& BERGSTRÖM, S. M. 1998. Isotopic evidence for geochemical decoupling between ancient epeiric seas and bordering oceans: implications for secular curves. Geology 26, 567-70.

HuDSON, J. D. 1977. Stable isotopes and limestone lithification. Journal of the Geological Society, London 133, 637-60.

Immenhauser, A., Della Porta, G., Kenter, J. A. M. \& BAHAMONDE, J. R. 2003. An alternative model for positive shifts in shallow-marine carbonate $\delta^{13} \mathrm{C}$ and $\delta^{18}$ O. Sedimentology 50, 953-9.

Immenhauser, A., Holmden, C. \& PATterson, W. P. 2007. Interpreting the carbon-isotope record of ancient epeiric seas: lessons from the Recent. In Dynamics of Epeiric Seas (eds B. R. Pratt \& C. Holmden), pp. 137-74. Geological Association of Canada, Special Paper no. 48.

Immenhauser, A., Kenter, J. A. M., Ganssen, G., BAHAMONDE, J. R., VAN Vliet, A. \& SAHER, M. H. 2002. Origin and significance of isotope shifts in Pennsylvanian carbonates (Asturias, NW Spain). Journal of Sedimentary Research 72, 82-92.

JAFFREZO, M. \& RENARD, M. 1979. Eléments en traces de calcaires à Dasycladales et Charophytes. In Second International Symposium on Fossil Algae (eds A. F. Poignant \& R. Deloffre), pp. 639-49. New York, 
Oxford: Elsevier, Bulletin du Centre de Recherches Exploration-Production Elf-Aquitaine, Introduction to Marine Micropaleontology.

Jenkyns, H. C., Jones, C. E., Gröcke, D. R., Hesselbo, S. P. \& PARKINSON, D. N. 2002. Chemostratigraphy of the Jurassic System: applications, limitations and implications for palaeoceanography. Journal of the Geological Society, London 159, 351-78.

JOACHIMSKI, M. M. 1994. Subaerial exposure and deposition of shallowing-upward sequences: evidence from stable isotopes of Purbeckian peritidal carbonates (basal Cretaceous), Swiss and French Jura Mountains. Sedimentology 41, 805-24.

JOACHIMSKI, M. M., SIMON, L., VAN GELDERN, R. \& LÉCUYER, C. 2005. Boron isotope geochemistry of Paleozoic brachiopod calcite: implications for a secular change in the boron isotope geochemistry of seawater over the Phanerozoic. Geochimica et Cosmochimica Acta 69, 4035-44.

Kendall, M. G. \& GiBBons, J. D. 1990. Rank Correlation Methods, 5th ed. London: Edward Arnold.

KINSMAN, D. J. J. 1969. Interpretation of $\mathrm{Sr}^{2+}$ concentrations in carbonate minerals and rocks. Journal of Sedimentary Petrology 39, 486-508.

Krull, E. S., Lehrmann, D. J., Druke, D., Kessel, B., YU, Y. Y. \& LI, R. 2004. Stable carbon isotope stratigraphy across the Permian-Triassic boundary in shallow marine carbonate platforms, Nanpanjiang Basin, south China. Palaeogeography Palaeoclimatology Palaeoecology 204, 297-315.

LAND, L. S. \& Hoops, G. K. 1973. Sodium in carbonate sediments and rocks: a possible index to the salinity of diagenetic solutions. Journal of Sedimentary Petrology 43, 614-17.

LlOYD, R. M. 1962. Variations in the oxygen and carbon isotope ratios of Florida Bay mollusks and their environmental significance. Journal of Geology 72, 84111.

LOHMANN, K. C. 1988. Geochemical patterns of meteoric diagenetic systems and their application to studies of paleokarst. In Paleokarst (eds N. P. James \& P. W. Choquette), pp. 58-80. Springer-Verlag.

Machel, H. G., Mason, R. A., Mariano, A. N. \& MuCCI, A. 1991. Causes and emission of luminescence in calcite and dolomite. In Luminescence Microscopy: Quantitative and qualitative aspects (eds C. E. Barker \& D. C. Kopp), pp. 9-25. SEPM Short Course.

MAgARITZ, M. 1983. Carbon and oxygen isotope composition of recent and ancient coated grains. In Coated Grains (ed. T. M. Peryt), pp. 27-30. Berlin: SpringerVerlag.

Marshall, J. D. \& Middleton, P. D. 1980. Changes in marine isotopic composition and the late Ordovician glaciation. Journal of the Geological Society, London 147, $1-4$.

MARSHALL, J. D. 1992. Climatic and oceanographic isotopic signals from the carbonate rock record and their preservation. Geological Magazine 129, 143-60.

McConnaughey, T. $1989 a .{ }^{13} \mathrm{C}$ and ${ }^{18} \mathrm{O}$ isotopic disequilibrium in biological carbonates: I. Patterns. Geochimica et Cosmochimica Acta 53, 151-62.

McConnaugheY, T. $1989 \mathrm{~b} .{ }^{13} \mathrm{C}$ and ${ }^{18} \mathrm{O}$ isotopic disequilibrium in biological carbonates: II. In vitro simulation of kinetic isotope effects. Geochimica et Cosmochimica Acta 53, 163-71.

McConnaughey, T., Burdett, J., Whelan, J. F. \& PAULl, C. K. 1997. Carbon isotopes in biological carbonates: respiration and photosynthesis. Geochimica et Cosmochimica Acta 61, 611-22.

Meyer, C. \& Pittman, J. G. 1994. A comparison between the Brontopodus ichnofacies of Portugal, Switzerland and Texas. Gaia 10, 125-33.

Milliman, J. D., Freile, D., Steinen, R. P. \& Wilber, R. J. 1993. Great Bahama Bank aragonitic muds: mostly inorganically precipitated, mostly exported. Journal of Sedimentary Petrology 63, 589-95.

Moore, C. H. 2001. Carbonate Reservoirs: Porosity evolution and diagenesis in a sequence stratigraphic framework. Elsevier.

Morettini, E., SAntantonio, M., Bartolini, A. \& Cecca, F., Baumgartner, P. O. \& HunZiKer, J. C. 2002. Carbon isotope stratigraphy and carbonate production during the Early-Middle Jurassic: examples from the Umbria-Marche-Sabina Apennines (central Italy). Palaeogeography Palaeoclimatology Palaeoecology 184, 251-73.

Morgans-Bell, H. S., Coe, A. L., Hesselbo, S. P., Jenkyns, H. C., WeEdon, G. P., Marshall, J. E. A., Tyson, R. V. \& Williams, C. J. 2001. Integrated stratigraphy of the Kimmeridge Clay Formation (Upper Jurassic) based on exposures and boreholes in south Dorset, UK. Geological Magazine 138, 51139.

Morse, J. W., Millero, F. J., Thurmond, V., Brown, E. \& OstLund, H. G. 1984. The carbonate chemistry of Grand Bahama Bank waters: after 18 years another look. Journal of Geophysical Research 89, 3604-14.

Padden, M., Weissert, H., FunK, H., Schneider, S. \& GANSNER, C. 2002. Late Jurassic lithological evolution and carbon-isotope stratigraphy of the western Tethys. Eclogae geologicae Helvetiae 95, 333-46.

Panchuk, K. M., Holmden, C. \& Kump, L. R. 2005. Sensitivity of the epeiric sea carbon isotope record to local-scale carbon cycle processes: tales from the Mohawkian Sea. Palaeogeography Palaeoclimatology Palaeoecology 228, 320-37.

PanchuK, K. M., Holmden, C. E. \& Leslie, S. A. 2006. Local controls on carbon cycling in the Ordovician midcontinent region of North America, with implications for carbon isotope secular curves. Journal of Sedimentary Research 76, 200-11.

Patterson, W. P. \& Walter, L. M. 1994a. Depletion of ${ }^{13} \mathrm{C}$ in seawater $\mathrm{CO}_{2}$ on modern carbonate platforms: significance for the carbon isotopic record of carbonates. Geology 22, 885-8.

Patterson, W. P. \& WALter, L. M. 1994b. Syndepositional diagenesis of modern platform carbonates: evidence from isotopic and minor element data. Geology 22, 127 30.

PRICE, G. D. 1999. The evidence and implications of polar ice during the Mesozoic. Earth-Science Reviews 48, 183210.

PRICE, G. D. \& GRÖCKE, D. R. 2002. Strontium-isotope stratigraphy and oxygen- and carbon-isotope variation during the Middle Jurassic-Early Cretaceous of the Falkland Plateau, South Atlantic. Palaeogeography Palaeoclimatology Palaeoecology 183, 209-22.

PRICE, G. D. \& RogOV, M. A. 2009. An isotopic appraisal of the Late Jurassic greenhouse phase in the Russian Platform. Palaeogeography Palaeoclimatology Palaeoecology 273, 41-9.

Prokoph, A., Shields, G. A. \& VeIZER, J. 2008. Compilation and time-series analysis of a marine carbonate $\delta^{18} \mathrm{O}$ $\delta^{13} \mathrm{C},{ }^{87} \mathrm{Sr} /{ }^{86} \mathrm{Sr}$ and $\delta^{34} \mathrm{~S}$ database through Earth history. Earth-Science Reviews 87, 113-33. 
RAMEIL, N. 2005. Carbonate sedimentology, sequence stratigraphy, and cyclostratigraphy of the Tithonian in the Swiss and French Jura Mountains. GeoFocus 13, $1-246$.

RENARD, M. \& BLANC, P. 1971. Mise au point d'un protocole expérimental pour le dosage des éléments traces $(\mathrm{V}$, $\mathrm{Cr}, \mathrm{Mn}, \mathrm{Ni}, \mathrm{Sr}, \mathrm{Mo}$ ) par absorption atomique. Comptes Rendus de l'Académie des Sciences de Paris 272, 22858.

Riboulleau, A., Baudin, F., Daux, V., HantzPergue, P., RENARD, M. \& ZAKHAROV, V. 1998. Evolution de la paléotempératures des eaux de la plate-forme russe au cours du Jurassique supérieur. Comptes Rendus de l'Académie des Sciences de Paris, Sciences de la Terre et des Planètes 326, 239-46.

RicheBOIS, G. 1990. Dosage de quelques éléments traces dans les eaux naturelles et les roches carbonatées. Application à l'étude géochimique de la coupe du Kef (Tunisie). Diplôme d'Etudes Supérieures Memoir. Paris, France: Université P.-et-M. Curie, 90 pp.

RomaneK, C. S., Grossman, E. L. \& Morse, J. W. 1992. Carbon isotopic fractionation in synthetic aragonite and calcite: effects of temperature and precipitation rate. Geochimica and Cosmochimica Acta 56, 419-30.

SAVARD, M. M., VeIZER, J. \& Hinton, R. H. 1995. Cathodoluminescence at low $\mathrm{Fe}$ and $\mathrm{Mn}$ concentrations: A SIMS study of zones in natural calcites. Journal of Sedimentary Research A65, 208-13.

Scholle, P. A. \& ARThuR, M. A. 1980. Carbon isotope fluctuations in Cretaceous pelagic limestones: potential stratigraphic and petroleum exploration tool. American Association of Petroleum Geologists Bulletin 64, $67-87$.

Schweigert, G. \& CALlomon, J. H. 1997. Der bauhiniFaunenhorizont und seine Bedeutung fur die Korrelation zwischen tethyalem und subborealem Oberjura. Stuttgarter Beiträge zur Naturkunde, Serie B (Geologie und Paläontologie) 247, 1-69.

Sellwood, B. W., Valdes, P. J. \& Price, G. D. 2000. Geological evaluation of multiple general circulation model simulations of Late Jurassic palaeoclimate. $\mathrm{Pa}$ laeogeography Palaeoclimatology Palaeoecology 156, 147-60.

SOKAL, R. R. \& RoHLF, F. J. 1995. Biometry: The Principles and Practice of Statistics in Biological Research, 3rd ed. New York: W. H. Freeman and Co.

SwART, P. K. \& EBERLI, G. 2005. The nature of the $\delta^{13} \mathrm{C}$ of periplatform sediments: Implications for stratigraphy and the global carbon cycle. Sedimentary Geology 175, 115-29.

THALMANN, H. K. 1966. Zur Stratigraphie des oberen Malm im südlichen Berner und Solothurner Jura. Mitteilungen der Naturforschenden Gesellschaft des Kantons Solothurn 22, 4-25.
Turekian, K. K. 1972. Chemistry of the Earth. New York: Holt, Rinehart and Winston, Inc.; Physical Science and Technology series.

VAHRENKAMP, V. C. 1996. Carbon isotope stratigraphy of the Upper Kharaib and Shuaiba Formations: implications for the Early Cretaceous evolution of the Arabian Gulf region. Bulletin of the American Association of Petroleum Geologists 80, 647-62.

van Dongen, B. E., Schouten, S. \& SinNinghe DAMSTE, J. S. 2006. Preservation of carbohydrates through sulfurization in a Jurassic euxinic shelf sea: examination of the Blackstone Band TOC cycle in the Kimmeridge Clay Formation, UK. Organic Geochemistry 37, 1052-73.

VAN GELDERN, R., JOACHIMSKI, M. M., DAY, J., JANSEN, U., Alvarez, F., Yolkin, E. A. \& MA, X.-P. 2006. Carbon, oxygen and strontium isotope records of Devonian brachiopod shell calcite. Palaeogeography Palaeoclimatology Palaeoecology 240, 47-67.

VEIZER, J. 1983. Chemical diagenesis of carbonates: theory and application of trace element technique. In Stable Isotopes in Sedimentary Petrology (eds M. A. Arthur, T. F. Anderson, J. Veizer \& L. S. Land), pp. 3-1 to 3100. Dallas: SEPM Short Course.

Veizer, J., Ala, D., AzMY, K., Bruckschen, P., Buhl, D., Bruhn, F., Carden, G. A. F., Diener, A., Ebneth, S., Godderis, Y., JasPer, T., Korte, C., PAWEllek, F., Podlaha, O. G. \& Strauss, H. $1999 .{ }^{87} \mathrm{Sr} /{ }^{86} \mathrm{Sr}, \delta^{13} \mathrm{C}$ and $\delta^{18} \mathrm{O}$ evolution in Phanerozoic seawater. Chemical Geology 161, 59-88.

WeISSERT, H. \& MOHR, H. 1996. Late Jurassic climate and its impact on carbon cycling. Palaeogeography Palaeoclimatology Palaeoecology 122, 27-43.

WeIsSERT, H., LinI, A., Föllmi, K. \& KUHN, O. 1998. Correlation of Early Cretaceous carbon isotope stratigraphy and platform drowning events: a possible link? Palaeogeography Palaeoclimatology Palaeoecology 137, 189203.

WIERZBOWSKI, H. 2004. Carbon and oxygen isotope composition of Oxfordian-Early Kimmeridgian belemnite rostra: palaeoenvironmental implications for Late Jurassic seas. Palaeogeography Palaeoclimatology Palaeoecology 203, 153-68.

Wignall, P. B. \& Ruffell, A. H. 1990. The influence of a sudden climatic change on marine deposition in the Kimmeridgian of Northwest Europe. Journal of the Geological Society, London 147, 365-71.

ZEEBE, R. E. 1999. An explanation of the effect of seawater carbonate concentration on foraminiferal oxygen isotopes. Geochimica and Cosmochimica Acta 63, 20017.

Zeebe, R. E. \& Wolf-Gladrow, D. 2001. $\mathrm{CO}_{2}$ in Seawater: Equilibrium, Kinetics, Isotopes. Amsterdam: Elsevier. 